\title{
ÍNDICES DE MATURAÇÃO, PONTO DE COLHEITA E PADRÃO RESPIRATÓRIO DE GOIABAS 'KUMAGAI' E 'PALUMA'
}

\author{
FLAVIA CRISTINA CAVALINI
}

\begin{abstract}
Dissertação apresentada à Escola Superior de Agricultura "Luiz de Queiroz", Universidade de São Paulo, para obtenção do título de Mestre em Ciências, Área de Concentração: Fisiologia e Bioquímica de Plantas.
\end{abstract}

P I R A C I C A B A

Estado de São Paulo - Brasil

Maio - 2004 


\title{
ÍNDICES DE MATURAÇÃO, PONTO DE COLHEITA E PADRÃO RESPIRATÓRIO DE GOIABAS 'KUMAGAI' E 'PALUMA'
}

\author{
FLAVIA CRISTINA CAVALINI
}

Engenheiro Agrônomo

Orientador: Prof. Dr. ANGELO PEDRO JACOMINO

Dissertação apresentada à Escola Superior de Agricultura "Luiz de Queiroz", Universidade de São Paulo, para obtenção do título de Mestre em Ciências, Área de Concentração: Fisiologia e Bioquímica de Plantas.

P I R A C I C A B A

Estado de São Paulo - Brasil

Maio - 2004 


\section{Dados Internacionais de Catalogação na Publicação (CIP)}

DIVISÃO DE BIBLIOTECA E DOCUMENTAÇÃO - ESALQ/USP

\section{Cavalini, Flavia Cristina}

Índices de maturação, ponto de colheita e padrão respiratório de goiabas 'Kumagai' e 'Paluma' / Flavia Cristina Cavalini. - - Piracicaba, 2004.

69 p. : il.

Dissertação (mestrado) - - Escola Superior de Agricultura Luiz de Queiroz, 2004.

Bibliografia.

1. Etileno 2. Fisiologia pós-colheita 3. Goiaba 4. Maturação vegetal 5. Respiração vegetal 6 . Variedades vegetais I. Título

CDD 634.421

"Permitida a cópia total ou parcial deste documento, desde que citada a fonte - O autor" 
Aos meus pais,

\section{Maria Luiza Martin Cavalini Maique e José Orlando Cavalini (em memória)}

Que com amor e dedicação, me ensinaram a não desistir de meus ideais;

Ao meu companheiro,

\section{Ademir Diniz Neves}

Que estando longe me deu força para continuar e ao meu lado tornou meu caminho mais feliz;

...e a você, minha filha,

\section{Victória Maria Cavalini Diniz Neves}

Que nos momentos mais difíceis me abre um sorriso lindo e me chama de mamãe, fazendo tudo ficar maravilhoso, 


\section{AGRADECIMENTOS}

A Deus, por estar sempre presente guiando cada passo dado e iluminando minha vida.

À Escola Superior de Agricultura "Luiz de Queiroz", Universidade de São Paulo, por possibilitar a realização desse trabalho.

Ao senhor Luís Kumagai, pela atenção e fornecimento dos frutos de 'Kumagai'

A Val Frutas, em particular ao Eng ${ }^{\circ}$. Agr ${ }^{\circ}$. Ricardo V. Rossi, pela atenção e fornecimento dos frutos de 'Paluma'.

A CAPES, pela concessão da bolsa de estudo.

À Fapesp, pela concessão da bolsa de auxílio técnico.

Ao Prof. Dr. Angelo Pedro Jacomino, pela orientação e confiança em mim depositada, e principalmente pela compreensão e amizade.

Aos professores Ricardo Alfredo Kluge e Lázaro Eustáquio Pereira Perez, pela amizade e sugestões feitas durante a realização deste trabalho.

Aos funcionários do Departamento de Produção Vegetal, que de alguma forma colaboraram para a realização desse trabalho.

Aos funcionários do Departamento de Ciências Biológicas, especialmente a Maria Solizete Granziol Silva, que além de secretária, mostrou-se amiga.

Às companheiras de bebês Danila, Simone Guidetti, Daniela, Paulinha e Joane, que sabem o quão difícil é a missão de mãe pós-graduanda. 
Aos colegas e amigos Maria Cecília, Raquel, Carol, Lílian, Fabiana, Amanda, Maria Luiza, Rogério, Simone Lombardi, Oscar, Eliane, Gregori, Adriano, Henrique, Patrícia, Maria Teresa, Saulo e Ana Helena, pelo convívio e apoio neste período. Em especial a Ilana e Rafael pelos feriados e fins de semana no laboratório.

A todos os integrantes do grupo de pós-colheita da ESALQ, principalmente Aninha, Michele e Alexandra pelo auxílio na realização das análises.

A Marisa Azzolini, que em pouco tempo tornou-se grande amiga e que deixa muita saudade.

Ao técnico do Laboratório de Pós-colheita Marcos Trevisan, por tornar tudo mais fácil e prático.

Às minhas irmãs Claudia C. Cavalini e Norma C. Cavalini, que me ajudaram em muito para a realização deste trabalho.

E a todos que de alguma forma contribuíram para a realização deste trabalho 


\section{SUMÁRIO}

Página

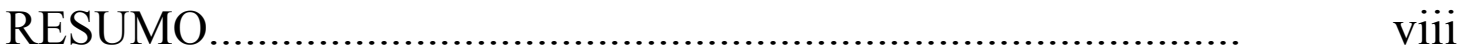

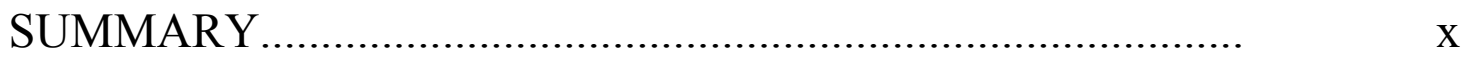

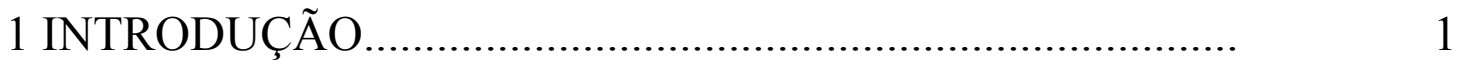

2 REVISÃO DE LITERATURA..............................................

2.1 Aspectos gerais sobre a cultura da goiabeira........................ 3

2.1.1 Variedade Kumagai..........................................................

2.1.2 Variedade Paluma............................................................

2.2 Ponto de colheita e qualidade do fruto..................................

2.2.1 Índices de maturação..........................................................

2.3 Desenvolvimento de frutos.................................................. 9

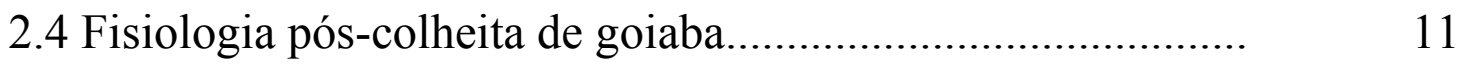

2.4.1 Respiração e padrão respiratório.......................................... 11

2.4.2 Etileno e padrões de amadurecimento.................................. 13

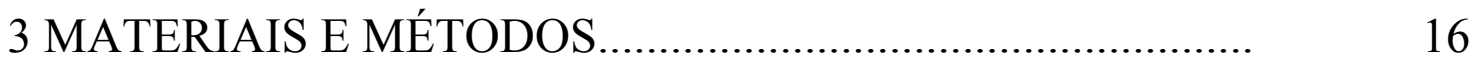

3.1 Caracterização de cinco estádios de maturação de goiabas

'Kumagai' e 'Paluma'........................................................... 16

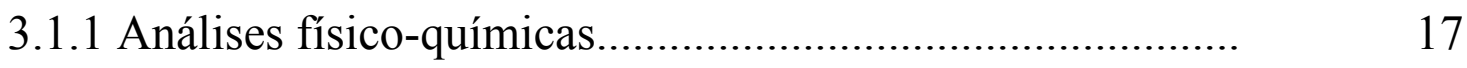

3.1.2 Delineamento estatístico e análise dos dados..................... 18

3.2 Influência do estádio de maturação na qualidade pós- 
colheita de goiabas 'Kumagai' e 'Paluma'.......................... 19

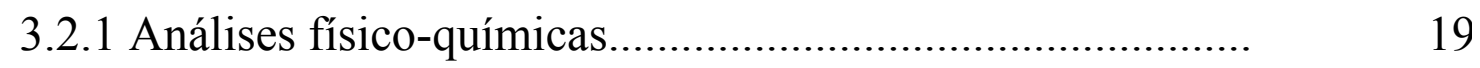

3.2.2 Análises sensoriais...................................................... 20

3.2.3 Delineamento estatístico e análise dos dados...................... $\quad 20$

3.3 Evolução físiológica e físico-química de goiabas 'Kumagai' e 'Paluma' durante o amadurecimento................................... 21

3.3.1 Análises físico-químicas................................................... 22

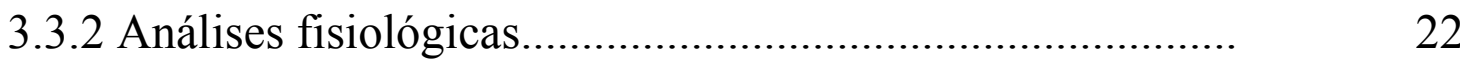

3.3.3 Delineamento estatístico e análise dos dados...................... 23

4 RESULTADOS E DISCUSSÃO.......................................... 24

4.1 Caracterização de cinco estádios de maturação de goiabas

'Kumagai 'e 'Paluma'........................................................ 24

4.2 Influência do estádio de maturação na qualidade póscolheita de goiabas 'Kumagai' e 'Paluma' .......................... 30

4.3 Evolução fisiológica e físico-química de goiabas 'Kumagai'

e 'Paluma' durante o amadurecimento................................. 37

4.3.1 Análise fisiológica........................................................... 37

4.3.2 Análise físico-química: transformações físico-químicas e a relação com a produção de etileno.....................................

5 CONCLUSÕES......................................................... 55

REFERÊNCIAS BIBLIOGRÁFICAS..................................... 56

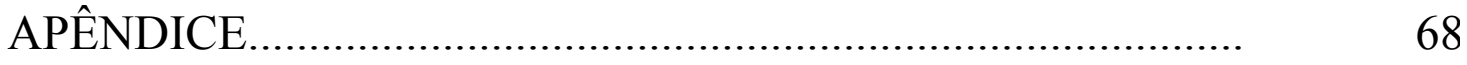




\title{
ÍNDICES DE MATURAÇÃO, PONTO DE COLHEITA E PADRÃO RESPIRATÓRIO DE GOIABAS 'KUMAGAI' E 'PALUMA'
}

\author{
Autora: FLAVIA CRISTINA CAVALINI \\ Orientador: Prof. Dr. ANGELO PEDRO JACOMINO
}

\section{RESUMO}

A goiaba é uma fruta altamente perecível, e o conhecimento de sua fisiologia póscolheita é fundamental para o emprego adequado de tecnologias, visando aumentar o período de conservação. O presente trabalho foi realizado com os objetivos de determinar índices de maturação; verificar a influência dos estádios de maturação na qualidade póscolheita e determinar o padrão respiratório para goiabas 'Kumagai' e 'Paluma'. Primeiramente determinaram-se os índices de maturação e a influência de cinco estádios de maturação na qualidade pós-colheita dos frutos. Os frutos foram selecionados em cinco estádios de maturação segundo a cor da casca: Estádio 1: cor da casca verdeescura; Estádio 2: quebra da cor verde; Estádio 3: início da coloração amarela da casca; Estádio 4: cor da casca parcialmente amarela; Estádio 5: frutos com cor da casca totalmente amarela, em seguida, foram armazenados em câmara a $25 \pm 2^{\circ} \mathrm{C}$ e $80-90 \%$ UR e avaliados quanto às mudanças físico-químicas e qualidade sensorial. 
Posteriormente determinou-se o padrão respiratório dos frutos, analisando-se a atividade respiratória, a produção de etileno e as mudanças físico-químicas após a colheita para os estádios 1,2 e 3 . A cor da casca e a firmeza foram consideradas os melhores índices de maturação para ambas as variedades. A variedade Paluma também apresentou o ratio como um bom índice de maturação. As variáveis físico-químicas apresentaram pouca variação entre os estádios de maturação após o amadurecimento, porém foram observadas diferenças significativas em relação à análise sensorial, sendo as melhores notas atribuídas aos estádios 4 e 5 na variedade Kumagai e para o estádio 5 na variedade Paluma. O ponto de colheita de goiabas 'Kumagai' não interferiu na firmeza da polpa, no teor de sólidos solúveis e no ratio ao final do período comercializável, apresentando os frutos do estádio 1 mais verdes, com menor teor de ácido ascórbico e maior acidez titulável. Em goiabas 'Paluma', o ponto de colheita não influenciou na cor da casca e no teor de sólidos solúveis. No geral, os frutos do estádio 1 apresentaram-se mais firmes, com menor teor de ácido ascórbico, mais ácidos, com cor da polpa mais clara e maior ratio. Tanto a variedade Kumagai quanto a Paluma apresentaram pico respiratório e de produção de etileno, independente do estádio de maturação, porém, estes ocorreram após o completo amadurecimento dos frutos. 


\title{
MATURATION RATES, HARVEST POINT AND RESPIRATORY STANDARD OF THE 'KUMAGAI' AND 'PALUMA' GUAVAS
}

\author{
Author: FLAVIA CRISTINA CAVALINI \\ Adviser: Prof. Dr. ANGELO PEDRO JACOMINO
}

\section{SUMMARY}

Guava is a highly perishable fruit and its post harvest physiology knowledgement is fundamental for the proper technology use in order to increase the preservation period. The present study was accomplished to determine the maturation rates; to verify the influence of the maturation levels in the post harvest and to determine the respiratory standard for the Kumagai and Paluma guavas. At first, the maturation rates and the influence of five levels of maturation in the post harvest of the fruit were determined. The fruits were selected in five levels of maturation according to the color of the peel: Level 1: a dark green color peel; Level 2: loss of the green color; Level 3: start of the yellow color of the peel; Level 4: a partially yellow color of the peel; Level 5: a totally yellow color of the fruits, and then, they were kept in a chamber at a percentage of $25 \pm$ $2{ }^{\circ} \mathrm{C}$ and $80-90 \%$ UR and evaluated as to the physico-chemical changes and sensory quality. After that, the respiration standard of the fruits was determined, analyzing the 
respiration activity, the production of ethylene and the physico-chemical changes after the harvest for the levels 1,2 and 3 . The color and the firmness of the peel were considered the best maturation rates for both varieties. The variety Paluma also showed the ratio as to a good maturation level. The physico-chemical variables showed less variation between the maturation levels after the ripeness, however significant differences were observed in relation to the sensorial analysis, obtaining the best performance for the levels 4 and 5 in the Kumagai variety and for the level 5 in the Paluma variety. The harvest point of the Kumagai guavas did nor interfere in the firmness of the flesh, in the content of the soluble solids and in the ratio to the end of the commerceable period, showing greener fruits in level 1 with a less content of ascorbic acid and a high titled acidic. In the Paluma guavas, the harvest point did not influence in the color of the peel and the content of soluble solids. In general, the fruits of level 1 showed firmer with a less content of ascorbic acid, more acidic with a lighter color of the flesh and a higher ratio. As the Kumagai as the Paluma varieties showed a respiratory peak and ethylene production independent of the maturation ratio, however these occurred after the complete ripeness of the fruits. 


\section{INTRODUÇÃO}

A cultura da goiabeira (Psidium guajava L.) é muito importante no contexto da fruticultura brasileira e encontra-se em crescente expansão. A produção brasileira de goiabas é de aproximadamente 280 mil toneladas, concentrada nos meses de fevereiro e março, mas a comercialização da fruta para consumo ocorre o ano todo.

Entre os anos de 2001 e 20002, houve aumento significativo da área plantada de aproximadamente $25 \%$ e da produção de aproximadamente $38 \%$, sem que o aumento da oferta viesse acompanhado de queda dos preços ao produtor. Ao contrário, houve um aumento desses preços da ordem de $50 \%$, o que sugere a ocorrência de aumento de consumo (FNP, 2004).

$\mathrm{O}$ aumento no consumo está associado à grande divulgação das qualidades nutricionais da fruta. A goiaba contém quatro vezes mais ácido ascórbico do que a laranja, quatro vezes mais cálcio do que o tomate e é rica em vitamina $\mathrm{E}$, fibras e licopeno, com o dobro da quantidade presente no tomate, além de apresentar alto teor de vitamina A, B6 e B2, quando comparada a outras frutas e legumes.

A goiaba constitui-se numa fruta altamente perecível devido a seu intenso metabolismo durante o amadurecimento e o uso de técnicas de conservação pós-colheita é imprescindível para aumentar o período viável de comercialização. Os atributos de qualidade são influenciados pelos cultivares, condições edafoclimáticas e práticas culturais.

Manejos inadequados na colheita e na pós-colheita aceleram os processos de senescência afetando sensivelmente a qualidade e limitando ainda mais o período de comercialização. 
Tem-se observado comportamento variado de goiabas, em pós-colheita, quanto ao padrão da atividade respiratória (climatérico ou não climatérico). Os frutos climatéricos são aqueles que apresentam um aumento da atividade respiratória e da síntese de etileno associado ao amadurecimento. Os frutos que não apresentam essa elevação na atividade respiratória e na síntese de etileno são considerados não-climatéricos. Este fato parece estar relacionado com a variedade (Botelho, 1996) e constitui-se em assunto divergente entre os autores. Alguns autores classificam-na como um fruto não climatérico (Biale \& Barcus, 1970; Chitarra \& Chitarra, 1990; Medina, 1978), porém outros julgam-na um fruto climatérico (Azzolini, 2002; Mercado-Silva et al., 1998; Oliveira, 1996).

Estes fatos têm dificultado o emprego adequado de técnicas de pós-colheita, como atmosfera modificada e refrigeração, por exemplo, que ora apresentam bom resultado e ora não. O padrão respiratório do fruto também é de grande importância para a definição do ponto de colheita ideal. De acordo com Awad (1993), a manipulação do amadurecimento é importante para garantir a extensão do período de comercialização dos produtos, sendo que para isto o conhecimento da fisiologia pós-colheita é indispensável.

Em face da potencialidade da cultura da goiaba para o Estado de São Paulo no mercado de frutas "in natura" e da carência de dados referentes a sua fisiologia póscolheita, o presente trabalho teve como objetivo:

- Determinar os índices de maturação adequados para goiabas 'Kumagai' e 'Paluma';

- Verificar a influência dos estádios de maturação na qualidade pós-colheita de goiabas 'Kumagai' e 'Paluma', e

- Determinar o padrão respiratório destas variedades. 


\section{REVISÃO DE LITERATURA}

\subsection{Aspectos gerais sobre a cultura da goiabeira}

A goiabeira é uma planta da família das Myrtaceae, originária da América Tropical, cultivada no Brasil desde o Rio Grande do Sul até o Maranhão destacando-se o Estado de São Paulo como o maior produtor do país (Pereira, 1995).

A goiaba tem boa aceitação no mercado de frutas in natura, apresentando elevado valor de comercialização (FNP, 2004). No Estado de São Paulo são cultivadas variedades de polpa branca, destinadas ao mercado in natura e as de polpa vermelha com dupla aptidão, mercado in natura e indústria. Segundo dados do anuário estatístico da agricultura brasileira (FNP, 2004), a produção de goiaba no Estado de São Paulo em 2001 foi de 114.427 toneladas.

Pomares conduzidos visando produção de fruta para mercado in natura requerem uma série de cuidados especiais, como: poda, irrigação, raleio e ensacamento dos frutos. A época normal de produção de goiabas no estado de São Paulo vai de janeiro a março. Entretanto, utilizando-se de sistemas de poda e irrigação, tem-se produção o ano todo. A goiabeira floresce aproximadamente, dois meses após a realização da poda e os frutos estão aptos a serem colhidos três a cinco meses após a floração, dependendo da época do ano (Pereira, 1995). 


\subsubsection{Variedade Kumagai}

A variedade Kumagai foi obtida de uma seleção realizada na região de Campinas, SP, como resultado do cruzamento da goiabeira Australiana com a goiabeira IAC-4. Pode ser considerada uma planta de porte e vigor médios, com ramos longos, esparramados e de grande produtividade. Esta cultivar produz frutos grandes, com 280 a 480 gramas, periforme, arredondados a oblongos, com a casca lisa, de consistência firme e resistente, de coloração verde-amarelada quando maduros, apresentando polpa branca, de boa espessura e firme, consistente, saborosa, levemente ácida, com a cavidade cheia e com poucas sementes (Manica et al., 2000).

\subsubsection{Variedade Paluma}

A variedade Paluma é um clone derivado da variedade Rubi - Supreme, a partir de sementes de polinização aberta. Foi obtida em Jaboticabal a partir de um programa de melhoramento. Possui fruto com peso variável $(140-250 \mathrm{~g})$, formato ovóide com pescoço curto, coloração da polpa vermelha intenso, pequena porcentagem de sementes e bom rendimento de polpa $(93,76 \%)$. Consistência firme, bom sabor e boa capacidade de conservação pós-colheita, adequados para produção de massa e consumo ao natural (Medina et al., 1991). Destaca-se por ser uma variedade muito produtiva, cujos frutos destinam-se tanto para indústria quanto para mercado "in natura".

\subsection{Ponto de colheita e qualidade do fruto}

O ponto de colheita constitui-se em uma importante causa de perda pós-colheita em produtos hortícolas. Em goiabas, o ponto de colheita é reconhecido, na prática, pelo tamanho, consistência e coloração externa da fruta que, para um mesmo local, varia com a cultivar, época do ano, idade da planta, tratos culturais. 
O estádio de maturação no momento da colheita determina a qualidade final do fruto. Quando colhidos imaturos, além da qualidade pobre, são muito susceptíveis às desordens fisiológicas. Por outro lado, quando colhidos muito maduros, entram rapidamente em senescência (Bleinroth et al., 1996). Não existe uma padronização e um consenso do estádio de maturação ideal para a colheita de goiabas. Estas normalmente são colhidas quando a polpa ainda está firme e a coloração da casca começa a mudar de verde-escuro para verde-claro ou começando amarelecer (Manica et al., 2000).

A determinação da fase de maturação com base apenas na aparência do fruto é falha, por ser uma medida subjetiva, sujeita a muitas variações e conseqüentemente à grande margem de erro. Em lotes de goiabas colhidas verifica-se, normalmente, grande desuniformidade quanto ao ponto de colheita.

Para que a colheita seja efetuada no momento correto, é necessário que se determine com precisão o estádio de maturação do fruto, lançando mão dos índices de maturação. Esses índices compreendem medidas físicas ou químicas que sofrem mudanças perceptíveis ao longo da maturação da fruta, eles devem assegurar a obtenção de frutas de boa qualidade no que se refere às características sensoriais, além de um comportamento adequado durante o armazenamento (Kluge et al., 2002).

\subsection{1 Índices de maturação}

Os índices de maturação devem ser baseados tanto nas variações ambientais quanto nas varietais, além de ser prático, para que possa ser utilizado de maneira eficiente pelos produtores.

\section{a) Firmeza}

Além da importância do ponto de vista econômico, já que afeta a qualidade do fruto, a firmeza tem efeito na resistência ao transporte, na conservação e no ataque a microrganismos (Awad, 1993). 
A diminuição da firmeza da polpa durante o amadurecimento é função principalmente, da perda da integridade da parede celular. A degradação das moléculas poliméricas constituintes da parede celular, como celulose, hemicelulose e pectina, gera alterações na parede celular levando ao amolecimento da polpa. Outros processos também podem levar ao amolecimento dos frutos, como a degradação do amido e a perda de turgor (Tucker, 1993).

A goiaba é rica em pectina, esta tem seu teor influenciado por fatores como variedade, estádio de maturação, época de desenvolvimento dos frutos e fatores climáticos (Adulsen \& Kadam, 1995; Dhingra et al., 1983). Alguns trabalhos têm mostrado redução de pectinas total e solúvel durante o amadurecimento (Dhillon et al., 1987; Esteves et al., 1984), enquanto que outros mostram haver um aumento (Mowlah and Itto, 1982).

A determinação da firmeza é uma forma prática de avaliar o estádio de maturação do fruto. Dhingra et al. (1983), consideraram verdes as goiabas com firmeza de 85 Newtons (N) e verde-amarelas aquelas com firmeza entre 51 e $66 \mathrm{~N}$.

\section{b) Cor}

A coloração dos frutos é um importante atributo de qualidade, não só por contribuir para uma boa aparência, mas também, por influenciar a preferência do consumidor. Durante o amadurecimento, a maioria dos frutos sofrem alterações na cor, principalmente da casca. Desta forma a cor torna-se um atributo importante na determinação do estádio de maturação.

As mudanças de coloração são resultantes principalmente da degradação da clorofila, mas também é resultado da síntese de pigmentos como carotenóides e antocianinas (Tucker, 1993). A degradação da clorofila ocorre em função das mudanças de $\mathrm{pH}$, de ácidos, do aumento dos processos oxidativos e da ação das clorofilases (Wills et al., 1998). A coloração da goiaba é devida a existência de pigmentos como clorofila, caroteno, xantofila e licopeno (Adsule \& Kadam,1995).

Segundo Mercado-Silva et al., (1998), a cor da casca é o melhor índice para indicar o estádio de maturação de goiabas. Para Bleinroth et al. (1992), deve-se ter 
cuidado em utilizar a cor como índice de maturação. Isto porque, frutos localizados em certas posições na copa, que recebem raios solares durante boa parte do dia e adquirem coloração muito intensa, resultam em falsa indicação do estádio de maturação.

\section{c) Ácido ascórbico}

A biossíntese do ácido ascórbico nos vegetais é um processo não completamente entendido. Segundo Smirnoff et al. (2001), a biossíntese do ácido ascórbico em plantas tem como precursor a D-manose e L-galactose.

A principal forma ativa do ácido ascórbico é o ácido ascórbico, mas o produto da sua oxidação, o ácido deidroascórbico, também é ativo (Pelletier \& Brassard, 1977). Segundo Mokady et al. (1984), as formas oxidadas e reduzidas do ácido ascórbico possuem valores biológicos semelhantes, sendo necessária a determinação de ambos os ácidos para a correta determinação do conteúdo de ácido ascórbico.

A goiaba é uma excelente fonte de ácido ascórbico, apresentando teores entre 80 e 372mg. $100^{-1} \mathrm{~g}$ (Seymour et al., 1993). O total de ácido ascórbico na goiaba é influenciado pela condição climática, temperatura, umidade do solo, cultivo e variedade (Chitarra, 1996). Danos mecânicos, apodrecimento e senescência promovem a desorganização da parede celular promovendo a oxidação do ácido ascórbico, provavelmente devido a presença das enzimas polifenol oxidase e ácido ascórbico oxidase (Mokady et al., 1984).

Durante o amadurecimento o teor de ácido ascórbico aumenta no fruto durante os estádios iniciais de desenvolvimento até a maturação total e, quando excessivamente maduro, o conteúdo diminui significativamente (Dhillon et al., 1987; Esteves et al. 1984; Vazquez-Ochoa \& Colinas-Leon, 1990).

\section{d) Teor de sólidos solúveis (SS)}

Os sólidos solúveis representam os compostos solúveis em água presentes nos frutos, como açúcares, vitaminas, ácidos, aminoácidos e algumas pectinas. O teor de SS é dependente do estádio de maturação no qual o fruto é colhido e geralmente aumenta 
durante a maturação pela biossíntese ou degradação de polissacarídeos (Chitarra \& Chitarra, 1990).

Segundo Carvalho (1994), os principais açúcares responsáveis pelo sabor doce dos frutos são a frutose, a glicose e a sacarose. A frutose compreende 59,93\% e 52,85\% do açúcar nas variedades branca e vermelha respectivamente (Mowlah \& Itoo, 1982).

Segundo Esteves \& Carvalho (1982), o aumento do grau de doçura durante a maturação está relacionado com a formação e o acréscimo contínuo de frutose.

A frutose e a glicose são originadas da degradação da sacarose e dos polissacarídeos de reserva como o amido. A degradação das hexoses fosfatadas ocorre na respiração via glicólise ou no ciclo das pentoses fosfato (Nultsch, 2000).

Após a colheita o teor de sólidos solúveis em goiaba parece não sofrer alterações significativas (Jacomino, 1999; Xisto, 2002), tal fato pode ser explicado pelo baixo teor de amido em goiabas. As formas de armazenamento de açúcares em goiaba são frutose, glicose e sacarose (Adsule \& Kadam, 1995; Bulk et al, 1997; Manica et al, 2000; Seymor et al, 1993).

\section{e) Acidez titulável}

A acidez titulável de um fruto é dada pela presença dos ácidos orgânicos. O teor desses ácidos tende a diminuir durante o processo de maturação devido à oxidação dos ácidos no ciclo dos ácidos tricarboxílicos em decorrência da respiração (Brody, 1996), sendo fundamentais na síntese de compostos fenólicos, lipídios e aromas voláteis (Chitarra \& Chitarra, 1990). Assim, a variação da acidez pode ser um indicativo do estádio de maturação do fruto, já que a acidez decresce em função do avanço da maturação.

Em goiaba, a acidez é devida, principalmente, à presença de ácido cítrico e málico e em menores quantidades, dos ácidos galacturônico e fumárico (Chan \& Kwok, 1976), podendo a acidez variar de 0,24 a $1,79 \mathrm{ml}$ de ácido cítrico.100g polpa ${ }^{-1}$ (Gehardt et al., 1997), o que permite classificá-la como sendo de sabor moderado e bem aceito pelo consumo de mesa. 


\section{f) Relação sólidos solúveis e acidez titulável (SS/AT) ou "ratio"}

A relação entre SS e AT fornece um indicativo do sabor do fruto, pois relaciona a quantidade de açúcares e ácidos presentes. Esta relação tende a aumentar durante a maturação, devido ao aumento nos teores de açúcares e à diminuição dos ácidos.

Deve-se ter cuidado em estabelecer esta relação, pois frutas insípidas, contendo baixos teores de ácidos e SS, apresentam relação elevada, o que pode conduzir a interpretações errôneas quanto à qualidade desta fruta (Chitarra \& Chitarra, 1990).

A relação SS/AT pode ser considerada um índice de maturação para goiabas em que valores acima de 25 são indesejáveis, pois as frutas apresentam sabor estranho (Chitarra et al., 1981). Segundo Reyes et al. (1976) a relação SS/AT para goiabas verdes é de 7,3, enquanto que as verde-maduras apresentam relações em torno de 7,8 e 16,5, respectivamente. Azzolini (2002) e Ojeda (2001), também observaram o mesmo comportamento para goiabas 'Pedro Sato'.

\subsection{Desenvolvimento de frutos}

O desenvolvimento de frutos pode ser dividido em cinco fases em função dos processos fisiológicos, são elas: crescimento, maturação, maturidade físiológica, amadurecimento e senescência. Estas fases descrevem os diferentes processos desde a formação até a morte do órgão. Entretanto, muitos processos são comuns entre as fases, dificultando a clara distinção entre as mesmas (Watada et al., 1984), Figura 1. 
Desenvolvimento

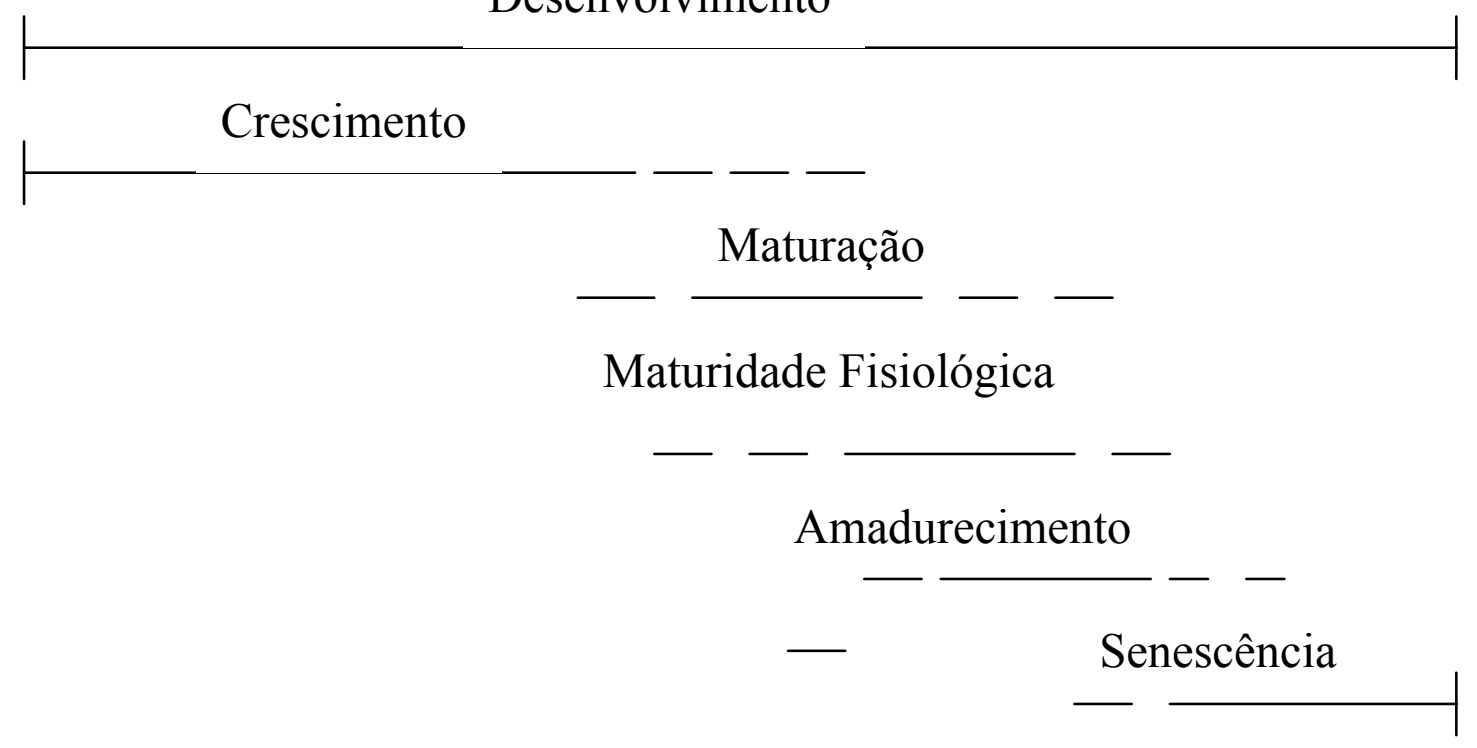

Figura 1- Fases do desenvolvimento baseado nos processos fisiológicos. (Modificado de Watada et al., 1984)

O crescimento é definido como a fase do desenvolvimento na qual ocorre o incremento irreversível nos atributos físicos. A maturação é o estádio do desenvolvimento que leva à maturação fisiológica e, a maturidade fisiológica é definida como o estádio do desenvolvimento em que a fruta continuará sua ontogenia, mesmo que destacada da planta (Watada et al., 1984).

Em relação à físiologia pós-colheita, o amadurecimento é uma fase importante do desenvolvimento dos frutos, pois os torna palatáveis e comercialmente atrativos em função das mudanças na coloração, textura, concentração de açúcares e compostos aromáticos, bem como, na acidez e compostos fenólicos. Tais mudanças são decorrentes do aumento da atividade enzimática, e no caso de frutos climatéricos, estão associadas a mudanças da atividade respiratória e biossíntese de etileno. $\mathrm{O}$ amadurecimento leva o fruto à senescência, fase final do processo de desenvolvimento (Rhodes, 1980; Vendrell \& Palomer, 1997). 
O estádio de maturação em que os frutos são colhidos é um fator determinante na qualidade pós-colheita. Segundo Castro \& Sigrist (1988), as condições do fruto na época da colheita determinam seu comportamento e, conseqüentemente, sua qualidade final.

\subsection{Fisiologia pós-colheita de goiaba}

\subsubsection{Respiração e padrão respiratório}

A respiração é o processo pelo qual os materiais orgânicos de reserva como carboidratos, proteínas e gorduras, são oxidados em moléculas mais simples $\left(\mathrm{CO}_{2}\right.$ e $\left.\mathrm{O}_{2}\right)$ com produção de energia e esqueleto carbônico (Kader,1992), que podem ser utilizados em reações de síntese. A energia liberada está sob duas formas: calor e ATP (Wills et al., 1998).

O processo de respiração é fundamental no amadurecimento dos frutos, pois várias reações acopladas à respiração são responsáveis pela síntese de inúmeros compostos tais como pigmentos, compostos fenólicos e fitohormônios (Purvis, 1997). Porém, a intensidade da respiração é também responsável pela longevidade das frutas em póscolheita, provocando modificações profundas nos constituintes químicos, principalmente em condições não controladas, levando à perda de umidade e à rápida senescência do fruto, interferindo assim, na qualidade do mesmo (Wills et al., 1981).

A atividade respiratória é naturalmente variável entre as diferentes espécies e estágios de desenvolvimento dos frutos. O padrão da atividade respiratória durante $\mathrm{o}$ amadurecimento é dividido em climatérico e não climatérico. Os frutos climatéricos são aqueles que apresentam um aumento na atividade respiratória durante 0 amadurecimento, já nos não climatéricos a elevação na taxa respiratória é ausente (Rhodes, 1980). Em geral o amadurecimento climatérico também está associado ao aumento da produção de etileno (Lelièvre et al., 1997). Segundo Giovannoni (2001), em frutos climatéricos o etileno é necessário para coordenar e completar o amadurecimento. 
Wills et al. (1998) afirma que nos frutos não climatéricos a respiração diminui durante o amadurecimento e as transformações bioquímicas que tornam o fruto maduro ocorrem de forma mais lenta.O amadurecimento só ocorre se o fruto estiver aderido a planta, diferentemente dos frutos climatéricos que possuem a capacidade de amadurecer mesmo após a colheita.

O padrão respiratório é um aspecto importante na definição do ponto de colheita. Os frutos climatéricos podem ser colhidos na maturidade fisiológica, já que estes continuam o amadurecimento após a colheita. Entretanto, os frutos não climatéricos completam o amadurecimento quando destacados da planta (Rhodes, 1980).

Os dados sobre a fisiologia pós-colheita de goiabas são limitados e contraditórios. Parece haver distintos comportamentos quanto ao padrão respiratório, em função da variedade. Para Biale \& Barcus (1970), a goiaba é um fruto não climatérico que não apresenta aumento brusco da liberação de $\mathrm{CO}_{2}$ ou aumento acentuado na incorporação de $\mathrm{O}_{2}$. Os autores estudaram variedades Amazônicas e relatam que a taxa de produção $\mathrm{CO}_{2}$ foi de 35 a $46 \mathrm{ml} / \mathrm{kg} / \mathrm{h}$. Chitarra \& Chitarra (1990) e Medina (1978) também consideram a goiaba como fruto não climatérico. Já Akamine \& Goo (1979) analisaram a respiração de duas cultivares de Psidium guajava e duas de Psidium cattleianum, no estádio de plena maturação e verificaram que todas apresentaram respiração climatérica e pico de produção de etileno bem definidos.

Goiabas indianas 'Sardar' colhidas no início da mudança da coloração da casca e armazenadas a $24^{\circ} \mathrm{C}$ e $85 \%$ de umidade relativa apresentaram elevação da taxa respiratória de $53 \mathrm{mg} \mathrm{CO} 2 \cdot \mathrm{kg}^{-1} \cdot \mathrm{h}^{-1}$, na colheita, para $82 \mathrm{mg} \mathrm{CO} 2 \cdot \mathrm{kg}^{-1} \cdot \mathrm{h}^{-1}$, depois de 6 dias (Singh et al., 1981).

Brown \& Wills (1983) estudaram o comportamento de 6 cultivares de $P$. guajava colhidas em quatro diferentes estádios de maturação, desde frutos imaturos a totalmente desenvolvidos. Todas as cultivares examinadas tiveram comportamento respiratório e de produção de etileno do tipo climatérico. Os frutos mais maduros alcançaram o pico climatérico 4 a 6 dias após a colheita, enquanto os frutos imaturos apresentaram menor produção de etileno e de $\mathrm{CO}_{2}$ e não completaram seu desenvolvimento. 
Oliveira (1996), observou comportamento do tipo climatérico para goiaba branca 'Kumagai', a qual apresentou pico de respiração de $51,38 \mathrm{ml} \mathrm{CO}_{2} \cdot \mathrm{kg}^{-1} \cdot \mathrm{h}^{-1}$ nove dias após a colheita para frutos armazenados a $21-29^{\circ} \mathrm{C}$ e $65-83 \% \mathrm{UR}$.

Mercado-Silva et al. (1998), no México, concluíram que a goiaba 'Media China' apresenta padrão climatérico tanto para produção de gás carbônico quanto de etileno. Observa-se, entretanto, neste trabalho, que o pico climatérico ocorre quando a fruta já está completamente amarela e amolecida, ou seja, já no final da vida útil, numa fase que mais parece com senescência do que com amadurecimento.

Para a variedade Pedro Sato, Azzolini (2002), observou aumento gradual da atividade respiratória, com atividade máxima após o completo amadurecimento.

\subsubsection{Etileno e padrões de amadurecimento}

Os processos que envolvem a biossíntese e a ação do etileno são complexos, e são dependentes de várias condições endógenas e exógenas do vegetal. Para Leliévre et al. (1997), o etileno pode promover diferentes respostas em função do estágio de desenvolvimento, das condições ambientais e da espécie ou mesmo da variedade.

O hormônio do amadurecimento, como é conhecido o etileno, é formado a partir do aminoácido metionina via SAM (S-adenosil L-metionina). O SAM é convertido à ACC (ácido 1-aminoacilciclopropano 1-carboxílico), sendo catalisado pela enzima ACC sintase. O ACC é então oxidado a etileno através da ação da enzima ACC oxidase (Figura 2), (Taiz \& Zeiger, 2004).

O etileno é biologicamente ativo em quantidades traço e seus efeitos são comercialmente importantes na agricultura (Abeles et al., et al., 1992). As taxas de produção de etileno pelos tecidos são geralmente baixas, e a concentração necessária para induzir o amadurecimento na fase pré-climatérica é dependente da espécie e estádio de maturação dos frutos (Yang, 1985). 


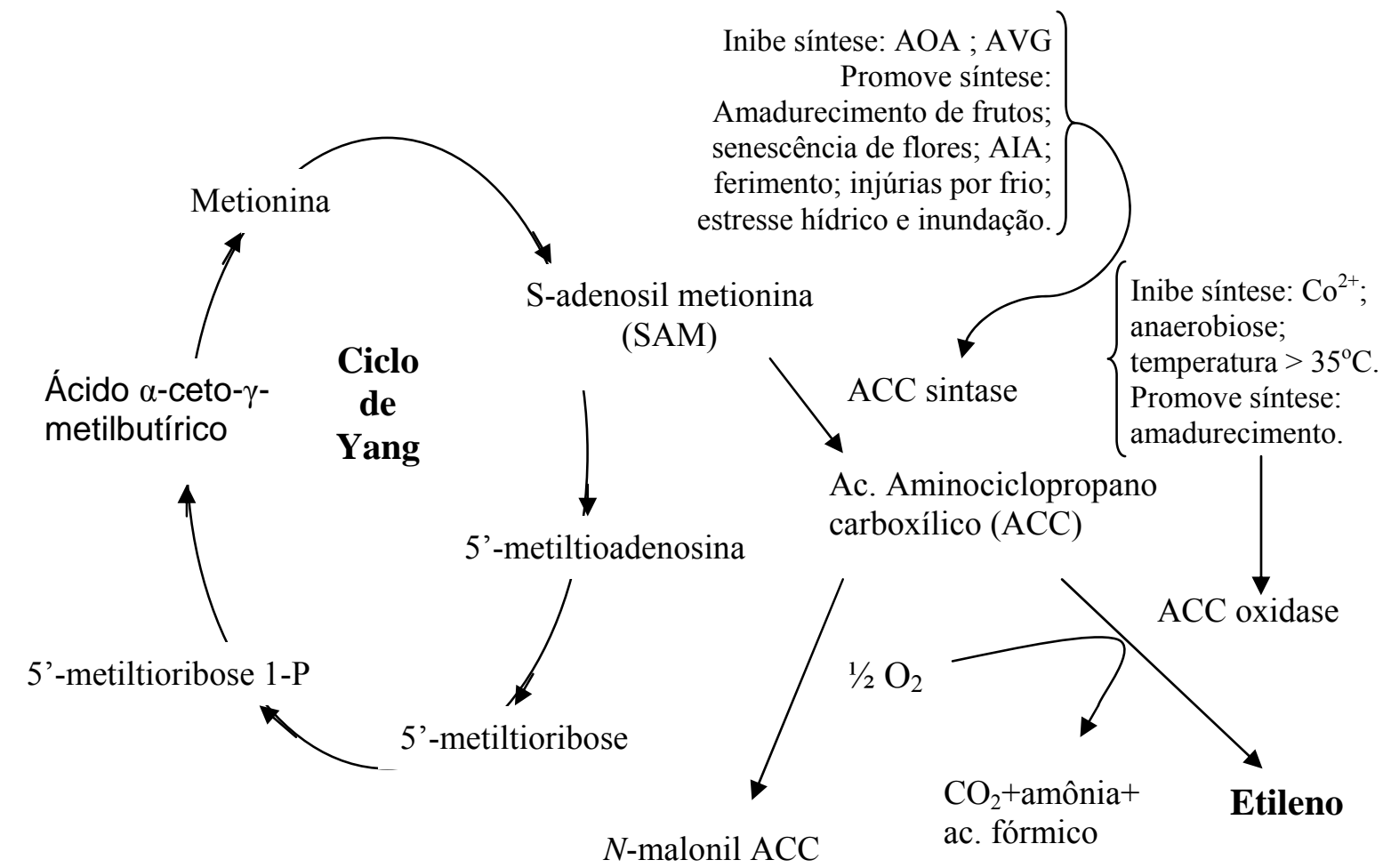

Figura 2- Esquema da via biossintética do etileno. (Modificado de Taiz \& Zeiger, 2004)

O etileno intervém, ao nível molecular, na indução da expressão de numerosos genes, que durante o amadurecimento parece ser regulada por dois caminhos, um é o etileno-dependente e outro o etileno-independente. De acordo com Taiz \& Zeiger (2004), genes envolvidos com a biossíntese de licopeno, aroma e metabolismo respiratório são considerados dependentes; já genes que codificam a enzima clorofilase e ACC oxidase parecem ser independentes do etileno. Em frutos climatéricos o etileno promove aumento da biossíntese das enzimas da sua própria rota metabólica, caracterizando a produção autocatalítica.

A ação do etileno é dependente da sua ligação a um receptor. Recentes estudos em Arabdopsis têm mostrado que este receptor possivelmente seja um complexo enzimático designado ETR1 (Fluhr \& Mattoo, 1996). Leliévre (1997) afirma que o etileno liga-se a este receptor, localizado na membrana celular, formando um complexo ativado que 
desencadeia um processo de reação em cascata, que levam à modificação da expressão gênica, com conseqüentes respostas fisiológicas e bioquímicas.

O aumento da biossíntese de etileno durante o climatérico é considerado o fator responsável pelo início do amadurecimento em frutos climatéricos (Abeles et al. et al., 1992; Biale, 1960; Grierson, 1987; McGlasson, 1985; Oetiker \& Yang, 1995).

McMurchie et al. (1972), distinguiram dois sistemas de produção de etileno (sistema I e sistema II), os quais estão associados com a fase pré-climatérica e climatérica. O sistema I é responsável pelos baixos níveis de produção de etileno presente no pré-climatérico e na produção de etileno dos tecidos vegetativos e frutos não climatéricos (Abeles et al. et al., 1992; Knee, 1985; Oetiker \& Yang, 1995).

A fase climatérica é decorrente do sistema II da biossíntese de etileno, no qual ocorre a produção autocatalítica. Segundo Vendrell \& Palomer (1997), o aumento da produção autocatalítica de etileno se deve ao aumento da atividade da ACC sintase.

Yang (1985), afirma que o que leva ao amadurecimento é a diminuição da resistência à ação do etileno, portanto, o aumento da produção de etileno pelo sistema I não seria pré-requisito para iniciar o amadurecimento. $\mathrm{O}$ autor classifica os frutos climatéricos em frutos do tipo I, os quais apresentam aumento na produção de etileno antes do começo do amadurecimento; e frutos do tipo II, nos quais o começo do amadurecimento não é precedido pelo aumento da produção de etileno.

Para Abdi et al. (1998), a classificação dos frutos em climatéricos e não climatéricos é uma grande simplificação do processo de amadurecimento.

Dada a importância do climatério no amadurecimento dos frutos, é importante que os eventos associados a esta fase sejam entendidos e caracterizados nas diferentes espécies e variedades de frutos. 


\section{MATERIAIS E MÉTODOS}

\subsection{Caracterização de cinco estádios de maturação de goiabas 'Kumagai ‘ e 'Paluma'}

Foram colhidas goiabas (Psidium guajava L.) das variedades Kumagai e Paluma, em pomares comerciais nos municípios de Campinas e Vista Alegre do Alto, respectivamente, em cinco estádios de maturação, segundo a cor da casca, de acordo com a seguinte escala:

Estádio 1- Fruto com coloração da casca verde-escura. Este estádio parece preceder a maturidade fisiológica, e é utilizado pelos agricultores quando os frutos serão transportados a longas distâncias.

Estádio 2- Fruto com quebra da cor verde. A cor da casca está mudando de verdeescuro para verde-claro. É provável que corresponda à maturidade fisiológica.

Estádio 3- Fruto com coloração da casca em início de desenvolvimento de cor amarela. Estádio comumente chamado pelos agricultores como "colorindo". Estes frutos precisam ser comercializados rapidamente, pois apresentam curto período de póscolheita.

Estádio 4- Frutos com coloração da casca parcialmente amarela. Os frutos deste estádio necessitam ser comercializado o mais breve possível.

Estádio 5- Fruto com coloração totalmente amarela. Normalmente destinado à indústria. 
Os frutos foram colhidos e selecionados segundo a cor da casca e ausência de defeitos, acondicionados em caixas plásticas forradas com espuma, para evitar danos mecânicos e transportadas imediatamente para o laboratório de Pós-Colheita do Departamento de Produção Vegetal da Escola Superior de Agricultura "Luiz de Queiroz" (ESALQ/USP).

No laboratório os frutos foram novamente selecionados de forma a obterem-se lotes uniformes e então acondicionados em câmara regulada para $25+1^{\circ} \mathrm{C}$ e $80-90 \%$ UR.

\subsubsection{Análises físico-químicas}

As goiabas foram submetidas a análises físico-químicas no momento em que chegaram ao laboratório e ao final do período comercializável. O final do período comercializável foi determinado através da coloração da casca, sendo esta totalmente amarela, a firmeza da polpa menor ou igual a $60 \mathrm{~N}$ para goiabas 'Kumagai' e menor ou igual a $15 \mathrm{~N}$ para goiabas 'Paluma' e o índice de podridão de no máximo $15 \%$.

- Cor da casca

A cor da casca foi determinada com colorímetro Minolta, modelo CR-300. Foram tomadas duas leituras por fruta, em lados opostos de sua região equatorial e os resultados expressos em ângulo de cor $\left(\mathrm{h}^{\circ}\right)$, de acordo com McGuirre (1992).

- Cor da polpa

Foi utilizada a mesma metodologia descrita para cor da casca. Os frutos foram cortados transversalmente, tomando-se uma leitura por fruto na região central e os resultados foram expressos em Cromaticidade (C).

A cor da polpa foi avaliada apenas para a variedade Paluma, uma vez que nesta variedade a cor da polpa muda de rosa-claro a vermelho intenso, enquanto que na variedade Kumagai praticamente não há mudanças na cor da polpa, que permanece de cor creme. 
- Firmeza

A firmeza foi determinada com penetrômetro digital, sendo a casca removida com o auxílio de um descascador manual, tomando-se duas leituras por fruta, em lados opostos na região equatorial, e os resultados expressos em Newton.

- Sólidos solúveis

O teor de sólidos solúveis foi obtido através de leitura direta em refratômetro marca Atago, modelo Pallete - 101 e os resultados expressos em ${ }^{\circ}$ Brix.

- Acidez titulável

A determinação da acidez titulável foi feita de acordo com metodologia descrita pela AOAC (1995) e os resultados expressos em porcentagem de ácido cítrico na polpa (\% Ác. cítrico).

- Ratio

O ratio foi determinado através da relação entre os teores de sólidos solúveis e de acidez titulável.

- Teor de ácido ascórbico

Foi determinado por titulometria, de acordo com metodologia descrita pela AOAC (1995), e os resultados expressos em mg de ácido ascórbico por 100g de polpa;

- Incidência de podridão

A incidência de podridão foi avaliada visualmente contando-se o número de goiabas com lesão. Os resultados foram expressos em porcentagem de goiabas com podridão.

- Perda de matéria fresca

Foi determinada pela diferença entre a massa inicial e a massa final da amostra em balança de precisão sendo os resultados expressos em porcentagem da massa inicial.

\subsubsection{Delineamento estatístico e análise dos dados}

O delineamento estatístico empregado foi inteiramente casualizado. Utilizaram-se 5 repetições de 3 frutos para cada tratamento e período de análise. 
Os dados foram submetidos à análise de variação pelo teste $\mathrm{F}$, utilizando-se o Sistema de Análise Estatística (SANEST), com médias comparadas pelo Teste de Tukey a $5 \%$ de probabilidade.

Com o objetivo de estabelecer as correlações existentes entre as variáveis físicoquímicas nos diferentes estádios de maturação foram calculados os coeficientes de correlação entre as variáveis estudadas, através de Planilha de dados, no Microsoft Excel.

3.2 Influência do estádio de maturação na qualidade pós-colheita de goiabas 'Kumagai' e 'Paluma'

Foram colhidas goiabas (Psidium guajava L.) das variedades Kumagai e Paluma, em pomares comerciais nos municípios de Campinas e Vista Alegre do Alto, respectivamente, em cinco estádios de maturação, segundo a cor da casca, de acordo com a escala citada no item 3.1 .

Os frutos foram colhidos e selecionados segundo a cor da casca e ausência de defeitos, acondicionados em caixas plásticas forradas com espuma, para evitar danos mecânicos e transportadas imediatamente para o laboratório de Pós-Colheita do Departamento de Produção Vegetal da Escola Superior de Agricultura "Luiz de Queiroz" (ESALQ/USP).

No laboratório os frutos foram novamente selecionados de forma a obterem-se lotes uniformes e então acondicionados em câmara regulada para $25+1{ }^{\circ} \mathrm{C}$ e $80-90 \%$ UR.

\subsubsection{Análises físico-químicas}

As goiabas foram submetidas a análises físico-químicas no momento em que chegaram ao laboratório e ao final do período comercializável como descrito no item .3.1. 


\subsubsection{Análises sensoriais}

As análises sensoriais foram realizadas ao final do período comercializável, tendo cada estádio atingido o completo amadurecimento em momentos distintos. Este período foi determinado pelas análises físico-químicas.

Os frutos foram lavados em água corrente, cortados em oito fatias longitudinais e acondicionados em bandejas de polietileno rígido, as quais foram fechadas com tampa própria (Figura 3). Foram colocadas duas fatias em cada bandeja. Logo após o preparo, as bandejas foram oferecidas aos provadores que avaliaram a amostra quanto ao odor, sabor, textura, aparência externa e qualidade global, de acordo com a seguinte escala de notas desenvolvida por Peryan et al. (1952): 1 = péssimo; 2 = muito ruim; $3=$ ruim; $4=$ regular; 5 = bom; $6=$ muito bom e $7=$ ótimo. $O$ modelo da ficha utilizada para avaliação das amostras encontra-se em anexo (Apêndice 1).

Para a avaliação da aparência externa, os provadores receberam uma amostra contendo cinco frutos inteiros acondicionados em bandeja plástica. A ficha de avaliação contou também com espaço para comentários do provador sobre as características mais e menos apreciadas no fruto. A análise foi realizada com 40 provadores não treinados.

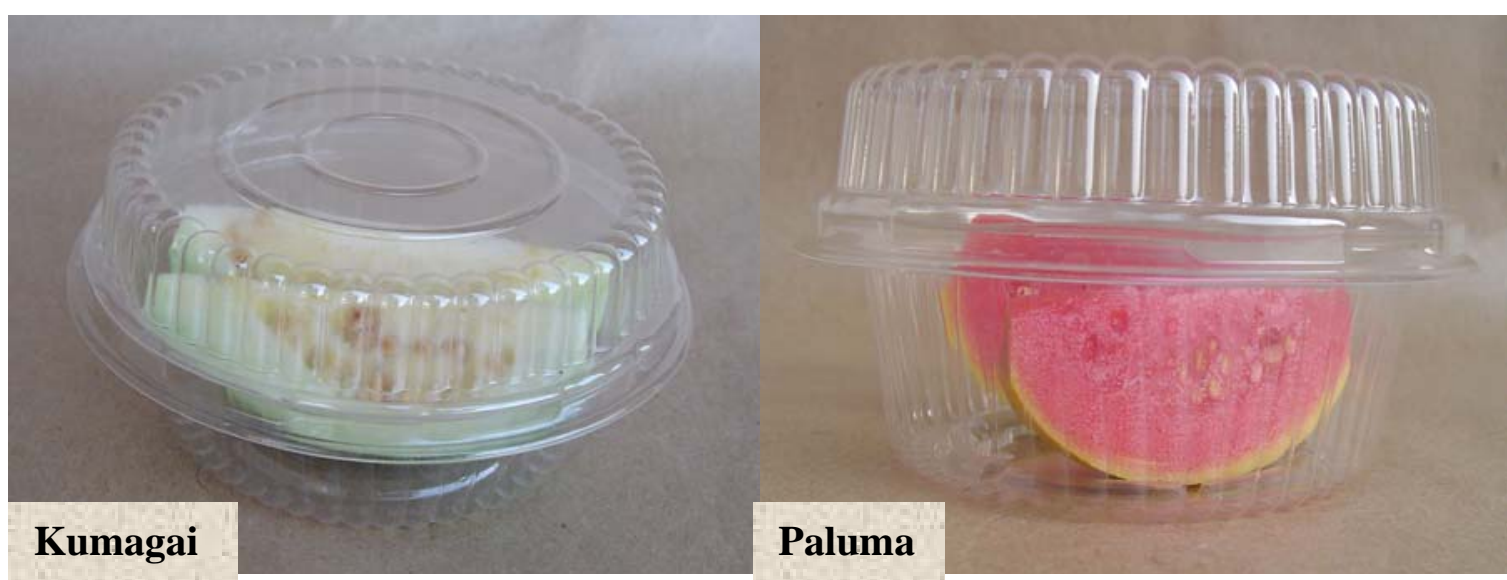

Figura 3- Amostra de goiaba acondicionada em embalagem, para análise sensorial

\subsubsection{Delineamento estatístico e análise dos dados}

O delineamento estatístico empregado foi inteiramente casualizado. Utilizaram-se 5 repetições de 3 frutos para cada tratamento e período de análise. Para a análise 
sensorial o delineamento foi blocos ao acaso, sendo cada provador considerado um bloco.

Os dados foram submetidos à análise de variação pelo teste $\mathrm{F}$, utilizando-se $\mathrm{o}$ Sistema de Análise Estatística (SANEST), com médias comparadas pelo Teste de Tukey a $5 \%$ de probabilidade.

\subsection{Evolução fisiológica e físico-química de goiabas 'Kumagai' e 'Paluma' durante o amadurecimento}

Foram colhidas goiabas (Psidium guajava L.) das variedades Kumagai e Paluma, em pomares comerciais nos municípios de Campinas e Vista Alegre do Alto, respectivamente, nos estádios de maturação 1 (fruto com coloração da casca verdeescura), 2 (fruto com quebra da cor verde) e 3 (fruto com coloração da casca em início de desenvolvimento de cor amarela), conforme descrito no item 3.1.

Os frutos foram colhidos e selecionados segundo a cor da casca e ausência de defeitos, acondicionados em caixas plásticas forradas com espuma, para evitar danos mecânicos e transportados imediatamente para o laboratório de Pós-Colheita do Departamento de Produção Vegetal da Escola Superior de Agricultura "Luiz de Queiroz" (ESALQ/USP).

No laboratório os frutos foram novamente selecionados de forma a obterem-se lotes uniformes e então tratados com fungicida prochloraz, por meio de imersão em solução na concentração de $0,250 \mathrm{mg} \cdot 1^{-1}$ durante 3 minutos. Os frutos foram acondicionados em câmara regulada para $25 \pm 1{ }^{\circ} \mathrm{C}$ e $80-90 \%$ UR. A utilização de fungicida foi necessária para evitar a interferência das podridões nas análises de respiração e produção de etileno. 


\subsubsection{Análises físico-químicas}

As goiabas foram submetidas a análises físico-químicas a cada dois dias, acompanhando as análises fisiológicas, até que se pudesse observar queda na taxa respiratória e que na produção de etileno. Foram avaliadas as variáveis: cor da casca, cor da polpa (apenas para a variedade Paluma), firmeza da polpa, teor sólidos solúveis, teor acidez titulável, ratio, teor de ácido ascórbico, incidência de podridão e perda de matéria fresca, de acordo com metodologia descrita no item 3.1.1.

\subsubsection{Análises fisiológicas}

As análises fisiológicas foram realizadas diariamente, até que se observasse queda na taxa respiratória e na produção de etileno ou até o apodrecimento dos frutos.

\section{- Taxa respiratória}

As goiabas tratadas com prochloraz foram acondicionadas em frascos herméticos, de vidro, com tampa de metal e septo de silicone, com capacidade para $600 \mathrm{ml}$. Utilizaram-se 5 repetições de 1 fruto para cada estádio, sendo 1 fruto por frasco. Os mesmos foram fechados diariamente e ao final de 30 minutos coletou-se amostras de $1 \mathrm{ml}$ de gás do interior dos frascos, utilizando-se seringa modelo Gastight, marca Hamilton de 2,5 ml. As amostras foram injetadas no cromatógrafo a gás (modelo GC Trace 2000, marca Thermofinnigan), com detector de ionização de chama (FID), utilizando-se uma coluna "Propak N". O gás de arraste utilizado foi o hidrogênio, a um fluxo de $30 \mathrm{ml} /$ minuto. As temperaturas mantidas no aparelho foram de $80^{\circ} \mathrm{C}$ para a coluna, $100^{\circ} \mathrm{C}$ no injetor, $250^{\circ} \mathrm{C}$ no detector e $350^{\circ} \mathrm{C}$ no metanador. Os resultados da respiração foram expressos em $\mathrm{ml}$ de $\mathrm{CO}_{2} / \mathrm{Kg}$ de goiaba/hora.

- Produção de etileno

A produção de etileno foi medida da mesma forma que a respiração, porém os frutos foram mantidos fechados nos frasco por duas horas, para que houvesse um acúmulo de etileno, possibilitando a leitura do mesmo. Utilizou-se alíquota do gás do 
interior do frasco de $2 \mathrm{~mL}$, permitindo a leitura de níveis mais baixos de etileno. Os resultados da produção de etileno foram expressos em $\mu \mathrm{L}$ de $\mathrm{C}_{2} \mathrm{H}_{4} / \mathrm{kg}$ de goiaba / hora.

\subsubsection{Delineamento e análises dos dados}

O delineamento estatístico empregado na análise físico-química foi inteiramente casualizado. Utilizaram-se 5 repetições de 3 frutos para cada tratamento e período de análise. Os dados foram submetidos à análise de variação pelo teste $\mathrm{F}$, utilizando-se o Sistema de Análise Estatística (SANEST), com médias comparadas pelo Teste de Tukey a $5 \%$ de probabilidade.

As análises fisiológicas foram avaliadas observando as curvas de respiração e produção de etileno e os dados submetidos à análise do desvio padrão. As diferenças entre dois tratamentos maiores que as somas de dois desvios padrões foram consideradas significativas. 


\section{RESULTADOS E DISCUSSÃO}

\subsection{Caracterização de cinco estádios de maturação de goiabas 'Kumagai' e 'Paluma'}

A caracterização dos estádios de maturação deve ser baseada em um conjunto de valores ou índices de maturação que permitam expressar a fase do desenvolvimento do fruto, remetendo cada estádio a uma qualidade sensorial. Na Tabela 1 encontram-se as características físico-químicas de goiabas 'Kumagai' e 'Paluma', colhidas em cinco estádios de maturação.

A firmeza da polpa de goiabas 'Kumagai' permitiu que se diferenciasse significativamente os estádios 1 dos demais e o estádio 2 do estádio 5, porém não possibilitou a diferenciação dos estádios 3, 4 e 5. Já para goiabas 'Paluma', através da firmeza da polpa só não foi possível diferenciar o estádio 4 do estádio 5. Os frutos de 'Kumagai' colhidos no estádio 1 apresentaram-se 1,6 vezes mais firmes que os frutos colhidos no estádio 5, enquanto os frutos de 'Paluma' colhidos no estádio 1 apresentaram-se 6,6 vezes mais firmes que os frutos colhidos no estádio 5 (Tabela 1), mostrando que a goiaba 'Paluma' apresenta maior variação de firmeza entre os estádios. 
Tabela 1. Características físico-químicas de goiabas 'Kumagai' e 'Paluma em cinco estádios de maturação, no momento da colheita

\begin{tabular}{|c|c|c|c|c|c|c|}
\hline \multirow[b]{2}{*}{ Índices de Maturação } & \multicolumn{6}{|c|}{ Estádios de Maturação ${ }^{1}$} \\
\hline & $\begin{array}{c}\text { Estádio } \\
1\end{array}$ & $\begin{array}{l}\text { Estádio } \\
2\end{array}$ & $\begin{array}{l}\text { Estádio } \\
3\end{array}$ & $\begin{array}{c}\text { Estádio } \\
\quad 4\end{array}$ & $\begin{array}{c}\text { Estádio } \\
5\end{array}$ & $\begin{array}{l}\text { CV } \\
(\%)\end{array}$ \\
\hline & \multicolumn{6}{|c|}{ 'Kumagai' } \\
\hline Firmeza $(\mathrm{N})$ & $106,05 \mathrm{a}$ & $85,52 \mathrm{~b}$ & $82,35 \mathrm{bc}$ & $72,30 \mathrm{bc}$ & $65,41 \mathrm{c}$ & 23 \\
\hline Cor da casca $\left({ }^{\circ} \mathrm{h}\right)$ & $118,09 \mathrm{a}$ & $117,08 \mathrm{a}$ & $115,16 \mathrm{~b}$ & $113,02 \mathrm{c}$ & $111,05 \mathrm{~d}$ & 1,1 \\
\hline $\begin{array}{l}\text { Teor de Ácido Ascórbico } \\
\qquad\left(\mathrm{mg} .100 \mathrm{~g}^{-1}\right)\end{array}$ & $103,28 \mathrm{~b}$ & $107,87 \mathrm{~b}$ & $105,38 \mathrm{~b}$ & $112,21 \mathrm{~b}$ & $128,36 \mathrm{a}$ & 6,3 \\
\hline Sólidos solúveis ( ${ }^{\circ}$ Brix $)$ & $6,00 \mathrm{a}$ & $6,18 \mathrm{a}$ & $6,74 \mathrm{a}$ & $6,40 \mathrm{a}$ & $6,60 \mathrm{a}$ & 6,6 \\
\hline Acidez Titulável (\%) & $0,59 \mathrm{a}$ & $0,53 \mathrm{a}$ & $0,57 \mathrm{a}$ & $0,56 \mathrm{a}$ & $0,56 \mathrm{a}$ & 7,3 \\
\hline \multirow[t]{2}{*}{ Ratio } & $10,10 \mathrm{a}$ & $11,62 \mathrm{a}$ & $11,93 \mathrm{a}$ & $11,46 \mathrm{a}$ & $11,76 \mathrm{a}$ & 9,2 \\
\hline & \multicolumn{6}{|c|}{ 'Paluma' } \\
\hline Firmeza $(\mathrm{N})$ & $132,50 \mathrm{a}$ & $74,74 \mathrm{~b}$ & $48,89 \mathrm{c}$ & $28,99 \mathrm{~d}$ & $20,06 \mathrm{~d}$ & 29 \\
\hline Cor da casca $\left({ }^{\circ} \mathrm{h}\right)$ & $114,42 \mathrm{a}$ & $108,05 \mathrm{~b}$ & $102,39 \mathrm{c}$ & $95,86 \mathrm{~d}$ & $89,76 \mathrm{e}$ & 2,8 \\
\hline Cor da polpa (C) & $24,51 \mathrm{~b}$ & $30,20 \mathrm{a}$ & $30,56 \mathrm{a}$ & $30,30 \mathrm{a}$ & $31,93 \mathrm{a}$ & 7,8 \\
\hline $\begin{array}{c}\text { Teor de Ácido Ascórbico } \\
\left(\mathrm{mg}^{\left.100 \mathrm{~g}^{-1}\right)}\right.\end{array}$ & $62,80 \mathrm{c}$ & $72,02 \mathrm{~b}$ & $70,32 \mathrm{bc}$ & $75,40 \mathrm{~b}$ & $84,94 \mathrm{a}$ & 6,0 \\
\hline Sólidos solúveis( $\left({ }^{\circ} \mathrm{Brix}\right)$ & $7,74 \mathrm{a}$ & $7,55 \mathrm{a}$ & $7,67 \mathrm{a}$ & $7,55 \mathrm{a}$ & $8,33 \mathrm{a}$ & 5,5 \\
\hline Acidez Titulável (\%) & $0,78 \mathrm{a}$ & $0,66 \mathrm{~b}$ & $0,61 \mathrm{~b}$ & $0,53 \mathrm{c}$ & $0,47 \mathrm{~d}$ & 4,9 \\
\hline Ratio & $9,88 \mathrm{~d}$ & $11,42 \mathrm{~cd}$ & $12,60 \mathrm{bc}$ & $14,20 \mathrm{~b}$ & $17,66 \mathrm{a}$ & 7,4 \\
\hline
\end{tabular}

Médias seguidas pela mesma letra na linha não diferem entre si pelo teste de Tukey a 5\% de probabilidade.

${ }^{1}$ Estádios de maturação no momento da colheita em função da cor da casca: 1- verde-escura; 2- quebra da cor verde; 3- Início da coloração amarela; 4- parcialmente amarela; 5- totalmente amarela. 


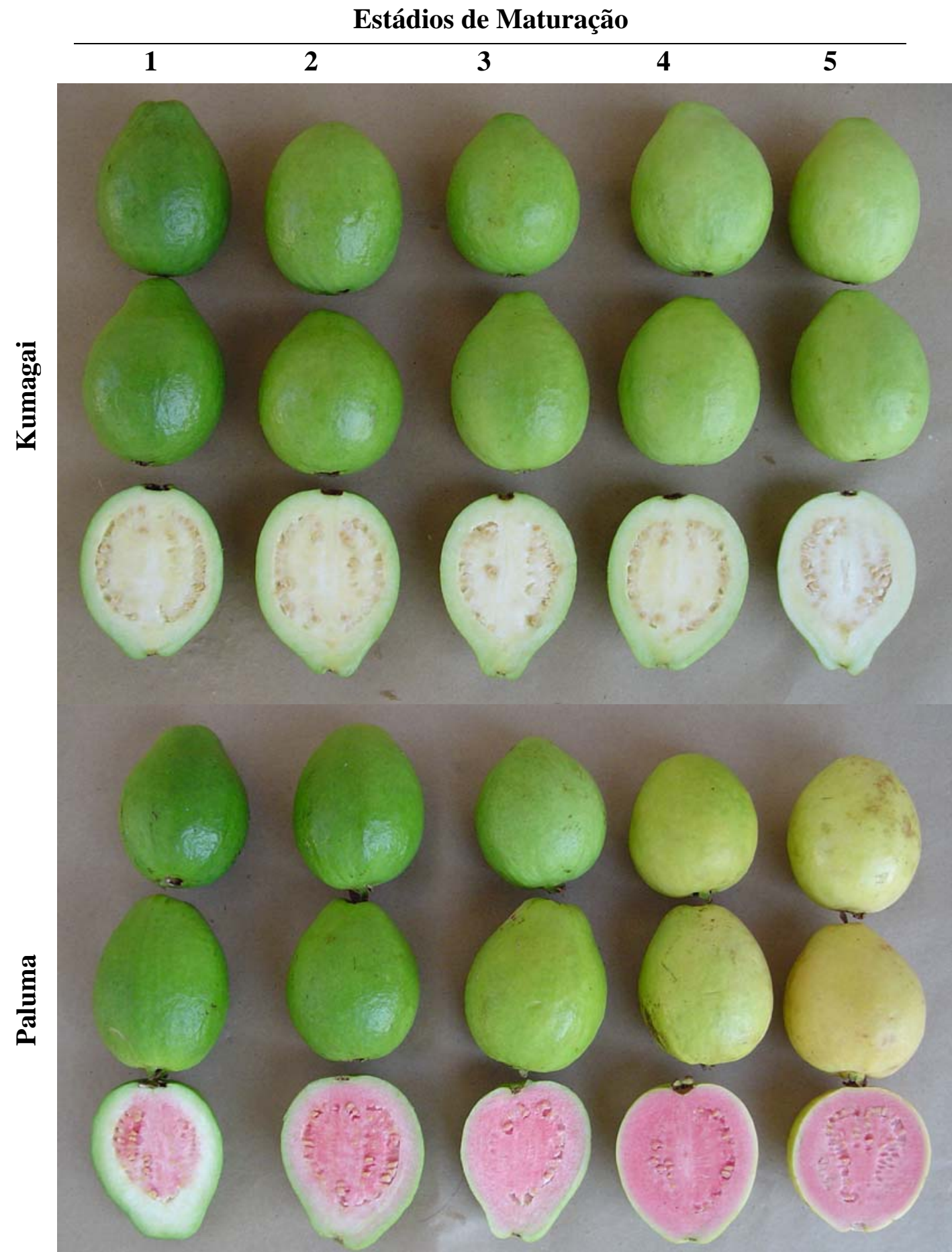

Figura 4- Estádios de maturação de goiabas recém colhidas, caracterizadas de acordo com a cor da casca: 1- verde-escura; 2- quebra da cor verde; 3- Início da coloração amarela; 4- parcialmente amarela; 5- totalmente amarela 
O ângulo de cor $\left(\mathrm{h}^{\circ}\right)$ pode variar de $0^{\circ}$ a $360^{\circ}$, sendo que $0^{\circ}$ corresponde a cor vermelha, $90^{\circ}$ corresponde ao amarelo, $180^{\circ}$ ao verde e $270^{\circ}$ ao azul. Em goiabas, o ângulo de cor expressa de forma significativa as mudanças da cor da casca. As goiabas verdes apresentam ângulo de cor maior que goiabas maduras.

A utilização da cor da casca como índice de maturação mostrou-se viável, pois permitiu diferenciar os estádios. Para goiabas ‘Kumagai' só não houve diferença entre os estádios 1 e 2, já para a variedade Paluma todos os estádios diferiram entre si. Esta variável apresenta baixo coeficiente de variação quando comparada às demais, o que permite uma maior confiabilidade dos resultados. Estes resultados estão de acordo com Azzolini (2002) que elegeu a cor da casca como melhor índice para a determinação do ponto de maturação de goiabas 'Pedro Sato' e de acordo com Mercado-Silva et al. (1998) que chegou nos mesmos resultados para goiabas 'Média China'.

A cor da polpa diferenciou apenas o estádio 1 dos demais. Observou-se que quanto mais avançado o ponto de colheita, maior o Croma, ou seja, maior a intensidade da cor da polpa. Esta variável foi avaliada apenas para a variedade Paluma, pois variedades de polpa branca, como Kumagai, não apresentam variação para este índice.

O teor de ácido ascórbico apresentou-se maior nos frutos colhidos em estádio mais avançado do amadurecimento, Jacomino (1999) também encontrou maior teor de ácido ascórbico em goiabas 'Kumagai' maduras do que em goiabas verdes. Para a variedade Kumagai foi possível diferenciar apenas o estádio 5 dos demais, tendo valores entre 128,36 e 103,28 mg ácido ascórbico. $100 \mathrm{~g}^{-1}$ polpa. A variedade Paluma apresentou maior diferenciação entre os estádios, sendo o estádio 5 diferente dos demais, os estádios $2,3 \mathrm{e}$ 4 não apresentaram diferença significativa entre si e o estádio 1 não diferenciou do estádio 3 a 5\% de significância. O teor de ácido ascórbico, para esta variedade, variou entre 84,94 e $62,80 \mathrm{mg} \cdot 100 \mathrm{~g}^{-1}$ polpa.

O teor de sólidos solúveis (SS) não apresentou diferenças significativas para nenhum dos 5 estádios, de ambas variedades. Os valores desta variável permaneceram entre 6,00 e $6,74^{\circ}$ Brix para os frutos da variedade Kumagai (Tabela 1) e entre 8,33 e $7,55^{\circ}$ Brix para os frutos da variedade Paluma. Esses valores são inferiores aos 
encontrados por Lima et al. (2002), para goiabas (Banahas, Lucknow 49 e Paluma) na região do Submédio São Francisco.

O amido, quando em alta concentração, contribui para o aumento do teor de SS durante o amadurecimento, porém a goiaba apresenta baixo teor de deste composto. $\mathrm{O}$ teor de sólidos solúveis em goiaba é representado por cerca de 51 a 91\% de açúcares totais (Rathore, 1976; Chitarra et al., 1981), sendo a frutose o principal componente. Sendo assim, o teor de SS está sujeito a inúmeras variações, tornando difícil determinar um intervalo do teor de SS que represente um estádio de maturação. Assim como Azzolini (2002) e Mercado-Silva et al. (1998) o teor de SS não representa um bom índice para caracterização dos estádios de maturação.

Assim como o teor de SS, a acidez titulável (AT) não apresentou diferença para nenhum dos 5 estádios de maturação para a variedade Kumagai. Os valores de AT variaram entre 0,53 e $0,59 \%$ de ácido cítrico. Os resultados de AT em goiabas 'Paluma' permitem afirmar que os frutos colhidos em estádios menos avançado do amadurecimento são mais ácidos que aqueles colhidos mais maduros. Assim como observou Azzolini (2002) para goiabas 'Pedro Sato' e Pivetta et al. (1992) para goiabas 'Paluma'. Os teores de AT variaram de $0,78 \%$ de ácido cítrico, no estádio 1 a $0,47 \%$, no estádio 5, e permitiram diferenciar a maioria dos estádios, com exceção dos estádios 2 e 3.

Os valores da relação SS/AT (ratio) para a variedade Kumagai variaram de 10,10 a 11,93, sendo que nenhum dos 5 estádios apresentou diferença significativa, o que discorda de Azzolini (2002) e Chitarra et al (1981) que sugerem a utilização do ratio como índice de maturação. Porém, para a variedade Paluma esta variável permitiu boa diferenciação dos estádios, (Tabela 1), podendo-se utilizá-la como índice de maturação para goiabas de polpa vermelha.

Utilizar-se mais de uma variável para caracterizar um estádio de maturação permite uma maior precisão ao se classificar os frutos em seus estádios. Entretanto, conhecer a correlação entre os índices de maturação, permite avaliar uma variável em função de outra. 
Verificou-se que para goiaba 'Kumagai' as melhores relações foram de cor da casca com firmeza da polpa e com teor de ácido ascórbico (Tabela 2).

A variedade Paluma apresentou bons coeficientes de correlação de cor da casca com firmeza da polpa, cor da polpa, teor de ácido ascórbico e acidez titulável (Tabela 3). Isto mostra que a cor da casca é realmente um bom indicativo do amadurecimento da fruta. O baixo valor do coeficiente de correlação entre o teor de sólidos solúveis e a cor da casca deve-se ao fato de que as mudanças no teor de SS são bastante discretas com o amadurecimento.

Tabela 2. Coeficiente de correlação entre as variáveis físico-químicas de goiabas 'Kumagai' colhidas em cinco estádios de maturação ${ }^{1}$

\begin{tabular}{cccccc}
\hline Variáveis & $\begin{array}{c}\text { Firmeza } \\
(\mathrm{N})\end{array}$ & $\begin{array}{c}\text { Teor de Ácido Ascórbico } \\
\left(\mathrm{mg} \cdot 100 \mathrm{~g}^{-1}\right)\end{array}$ & $\begin{array}{c}\text { Sólidos } \\
\text { Solúveis } \\
\left({ }^{\circ} \text { Brix }\right)\end{array}$ & $\begin{array}{c}\text { Acidez } \\
\text { Titulável } \\
(\%)\end{array}$ & Ratio \\
\hline $\begin{array}{c}\text { Cor da casca }\left({ }^{\circ} \mathrm{h}\right) \\
\text { Firmeza }(\mathrm{N})\end{array}$ & 0,60 & $-0,68$ & $-0,44$ & 0,07 & $-0,44$ \\
$\begin{array}{c}\text { Teor de Ácido Ascórbico } \\
\left(\mathrm{mg} .100 \mathrm{~g}^{-1}\right)\end{array}$ & & $-0,62$ & $-0,30$ & 0,45 & $-0,34$ \\
$\begin{array}{c}\text { Sólidos solúveis }\left({ }^{\circ} \mathrm{Brix}\right) \\
\text { Acidez Titulável }(\%)\end{array}$ & & & 0,28 & $-0,07$ & 0,28 \\
\hline
\end{tabular}

${ }^{1}$ Estádios de Maturação no momento da colheita em função da cor da casca: 1- verde-escura; 2- quebra da cor verde; 3- Início da coloração amarela; 4- parcialmente amarela; 5- totalmente amarela. 
Tabela 3. Coeficiente de correlação entre as variáveis físico-químicas de goiabas 'Paluma' colhidas em cinco estádios de maturação ${ }^{1}$, no momento da colheita

\begin{tabular}{|c|c|c|c|c|c|c|}
\hline Variáveis & $\begin{array}{c}\text { Firmeza } \\
(\mathrm{N})\end{array}$ & $\begin{array}{l}\text { Cor da } \\
\text { Polpa } \\
\text { (C) }\end{array}$ & $\begin{array}{c}\text { Teor de Ácido } \\
\text { Ascórbico }\left(\mathrm{mg}^{100 \mathrm{~g}^{-1}}\right)\end{array}$ & $\begin{array}{l}\text { Sólidos } \\
\text { Solúveis } \\
\left({ }^{\circ} \text { Brix }\right)\end{array}$ & $\begin{array}{c}\text { Acidez } \\
\text { Titulável } \\
(\%)\end{array}$ & Ratio \\
\hline Cor da casca $\left({ }^{\circ} \mathrm{h}\right)$ & 0,88 & $-0,64$ & $-0,79$ & $-0,36$ & 0,96 & $-0,93$ \\
\hline Firmeza $(\mathrm{N})$ & & $-0,79$ & $-0,72$ & $-0,18$ & 0,95 & $-0,82$ \\
\hline Cor da Polpa (C) & & & 0,67 & 0,25 & $-0,82$ & 0,73 \\
\hline Teor de Ácido & & & & 0,24 & $-0,76$ & 0,72 \\
\hline $\begin{array}{c}\text { Ascórbico } \\
\text { Sólidos Solúveis }\end{array}$ & & & & & $-0,24$ & 0,58 \\
\hline Acidez Titulável (\%) & & & & & & $-0,91$ \\
\hline
\end{tabular}

Estádios de Maturação no momento da colheita em função da cor da casca: 1- verde-escura; 2- quebra da cor verde; 3- Início da coloração amarela; 4- parcialmente amarela; 5- totalmente amarela.

\subsection{Influência do estádio de maturação na qualidade pós-colheita de goiabas 'Kumagai' e 'Paluma'}

O estádio de maturação no qual o fruto é colhido tem fundamental importância no período de comercialização (Chitarra \& Chitarra, 1990). Assim, frutos colhidos no início da maturação apresentam maior período pós-colheita em relação aos colhidos completamente maduros. Porém, a qualidade daqueles pode ser comprometida por distúrbios no processo de amadurecimento.

As características físico-químicas de goiabas 'Kumagai' e 'Paluma' colhidas em cinco estádios de maturação e armazenadas a $25 \pm 2{ }^{\circ} \mathrm{C}$ e $80-90 \%$ UR até o completo amadurecimento encontram-se na tabela 4.

O tempo de conservação das goiabas 'Kumagai' foi nitidamente maior do que da goiaba 'Paluma'. Os frutos de 'Kumagai' colhidos no estádio 5 encontraram-se completamente maduros com 4 dias após a colheita e aqueles colhidos no estádio 1, com 10 dias após a colheita. Já para a variedade Paluma, os frutos colhidos no estádio 5 conservaram-se apenas por apenas 1 dia e aqueles colhidos no estádio 1, por 6 dias. 
A goiaba é rica em pectinas, que juntamente com a fração fibra, são responsáveis pela integridade da parede celular. Com o avanço do amadurecimento ocorre a solubilização da pectina da parede celular e a diminuição da fração fibra (celulose e hemicelulose), tornando o fruto mais macio (Chitarra, 1996).

A firmeza da polpa de goiabas 'Kumagai' ao final do período comercializável variou de 56,38 a $36,28 \mathrm{~N}$ (Tabela 4). Embora não se tenha observado diferença significativa, em função do elevado coeficiente de variação, a diferença entre a firmeza do estádio 1 para a firmeza do estádio 5 foi de 1,5 vezes, valor semelhante aquele observado para essa variedade no momento da colheita.

$\mathrm{O}$ alto coeficiente de variação deve-se ao fato da grande desuniformidade observada durante o amadurecimento nos estádios 1 e 2 desta variedade. Além disso, a perda d'água associado a baixa perda de firmeza, dificultou as determinações no penetrômetro.

$\mathrm{Na}$ variedade Paluma a firmeza da polpa ao final do período comercializável variou de 22,44 $\mathrm{N}$ a 14,48 N. Embora tenha havido diferenças estatísticas entre os estádios, numericamente os valores são próximos. É importante observar que inicialmente a diferença entre os estádios 1 e 5 era de 6,6 vezes e após maduro, esta diferença é de 1,4 vezes.

Observa-se, portanto, que independentemente do ponto de colheita houve acentuada perda de firmeza nos frutos dessa variedade, em função do amadurecimento, enquanto que em goiabas 'Kumagai' a redução de firmeza foi no máximo de $50 \%$.

A coloração da casca é um importante atributo de qualidade, contribuindo para uma boa aparência e influenciando a preferência do consumidor (Clydesdal, 1993). O ângulo de cor permitiu notar a influência do ponto de colheita na qualidade dos frutos. Para a variedade Kumagai, foi possível diferenciar o estádio 1 dos demais, sendo este mais verde. Já para os frutos de 'Paluma' foi possível diferenciar apenas o estádio 1 do estádio 5. Nas duas variedades foi possível observar que todas as goiabas apresentaramse totalmente amarelas ao final do período comercializável, semelhante ao obtido por ElBuluk et al. (1995) e Jacomino et al. (2003), que observaram diminuição da coloração da casca (Figura 3). Estas diferenças são provavelmente devido ao maior conteúdo de clorofila presente inicialmente nos frutos colhidos no estádio 1. 
Tabela 4. Características físico-químicas de goiabas 'Kumagai' e 'Paluma' colhidas em cinco estádios de maturação e armazenadas a $25 \pm 2^{\circ} \mathrm{C}$ e $80-90 \%$ UR, até o completo amadurecimento

\begin{tabular}{|c|c|c|c|c|c|c|}
\hline \multirow{2}{*}{ Índices de Maturação } & \multicolumn{6}{|c|}{ Estádios de Maturação $^{1}$} \\
\hline & Estádio & Estádio $\mathrm{E}$ & Estádio & Estádio & Estádio & $\mathrm{CV}$ \\
\hline & \multicolumn{6}{|c|}{ Kumagai } \\
\hline Dias de armazenamento & 10 & 9 & 6 & 5 & 4 & - \\
\hline Firmeza $(\mathrm{N})$ & $56,38 \mathrm{a}$ & $40,44 \mathrm{a} \quad 4$ & $47,31 \mathrm{a}$ & $45,57 \mathrm{a}$ & $36,28 \mathrm{a}$ & 63,3 \\
\hline Cor da casca $\left({ }^{\circ} \mathrm{h}\right)$ & $115,47 \mathrm{a} \quad 10$ & $108,30 \mathrm{~b} \quad 10$ & $106,99 \mathrm{~b}$ & $108,62 \mathrm{~b}$ & $106,67 \mathrm{~b}$ & 4,3 \\
\hline Teor de Ácido Ascórbico & $98,18 \mathrm{~b}$ & $95,49 \mathrm{~b} \quad 14$ & 140,89 a & $152,62 \mathrm{a}$ & $157,60 \mathrm{a}$ & 10,8 \\
\hline Sólidos solúveis $\left({ }^{\circ} \mathrm{Brix}\right)$ & $6,90 \mathrm{a}$ & $7,34 \mathrm{a}$ & $7,18 \mathrm{a}$ & $7,40 \mathrm{a}$ & $7,30 \mathrm{a}$ & 5,3 \\
\hline Acidez Titulável (\%) & $0,68 \mathrm{a}$ & $0,65 \mathrm{a}$ & $0,65 \mathrm{a}$ & $0,59 \mathrm{ab}$ & $0,52 \mathrm{~b}$ & 9,0 \\
\hline Ratio & $10,18 \mathrm{c} \quad 11$ & $11,41 \mathrm{bc} 11$ & $11,07 \mathrm{bc}$ & $12,74 \mathrm{ab}$ & $14,07 \mathrm{a}$ & 9,8 \\
\hline Porcentagem de Podridão & 18 & 16 & 8 & 12 & 10 & - \\
\hline \multirow[t]{2}{*}{ Perda de matéria fresca $(\%)$} & 8 & 13 & 4 & 3 & 2 & - \\
\hline & \multicolumn{6}{|c|}{ Paluma } \\
\hline Dias de armazenamento & 6 & 4 & 3 & 2 & 1 & - \\
\hline Firmeza $(\mathrm{N})$ & $22,44 \mathrm{a}$ & a $20,86 \mathrm{ab}$ & b $\quad 19,34$ & b $\quad 15,48 \mathrm{c}$ & c $15,53 \mathrm{c}$ & 15,36 \\
\hline Cor da casca $\left({ }^{\circ} \mathrm{h}\right)$ & $90,99 \mathrm{a}$ & a $89,52 \mathrm{ab}$ & b 89,20 a & $\mathrm{ab} \quad 88,69 \mathrm{ab}$ & ab $87,57 \mathrm{~b}$ & 2,7 \\
\hline Cor da Polpa (C) & $38,23 \mathrm{a}$ & a $39,10 \mathrm{a}$ & 38,48 & a $\quad 34,61 b$ & b $\quad 32,31 \mathrm{c}$ & 4,8 \\
\hline 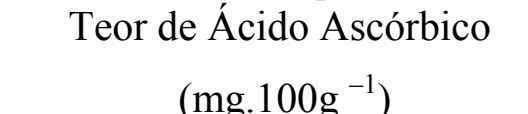 & $62,08 \mathrm{bc}$ & c $59,78 \mathrm{c}$ & 70,65 & $a b \quad 75,23 a$ & a $\quad 78,78$ a & 7,3 \\
\hline Sólidos solúveis $\left({ }^{\circ} \mathrm{Brix}\right)$ & $8,19 \mathrm{ab}$ & b $7,81 \mathrm{abc}$ & c 7,55 & $7,78 \mathrm{bc}$ & $8,41 \mathrm{a}$ & 4,1 \\
\hline Acidez Titulável (\%) & $0,75 \mathrm{a}$ & $0,66 \mathrm{~b}$ & $0,60 \mathrm{~b}$ & c $\quad 0,53 \mathrm{~cd}$ & $0,48 \mathrm{~d}$ & 6,2 \\
\hline Ratio & $10,91 \mathrm{c}$ & $11,86 \mathrm{c}$ & 12,66 & c $14,70 \mathrm{~b}$ & b $\quad 17,52 \mathrm{a}$ & 7,7 \\
\hline Porcentagem de Podridão & 18 & 25 & 20 & 18 & 19 & - \\
\hline Perda de matéria fresca (\%) & 11,4 & 3,4 & 3,4 & 2 & 2,1 & - \\
\hline
\end{tabular}

Médias seguidas pela mesma letra na linha não diferem entre si pelo teste de Tukey a 5\% de probabilidade.

${ }^{1}$ Estádios de maturação no momento da colheita em função da cor da casca: 1- verde-escura; 2- quebra da cor verde; 3- início da coloração amarela; 4- parcialmente amarela; 5- totalmente amarela.

Na variedade Paluma avaliou-se também a cor da polpa, e verificou-se que houve influência do ponto de colheita na cor da polpa ao final do período comercializável, sendo que as goiabas colhidas mais verdes atingiram polpa de coloração mais intensa que as colhidas mais maduras. Tais resultados foram observados por Azzolini (2002) em goiabas 'Pedro Sato' e Jacomino et al. (2003) para goiabas tratadas com emulsão de cera de carnaúba. Observou-se ainda que a goiaba desenvolveu a coloração interna, apresentando ao final do período comercializável, valores de croma superiores aos 
iniciais para todos os estádios de maturação. O que explica o desenvolvimento da cor vermelha em goiabas é a síntese de licopeno, que aumenta no decorrer da maturação (Adsule \& Kadam, 1995).

Os teores de ácido ascórbico, sólidos solúveis e acidez são características importantes na qualidade organoléptica e nutricional de frutos. Notou-se, em ambas variedades, que os estádios colhidos mais verdes desenvolveram menor teor de ácido ascórbico que os frutos mais maduros. Estes resultados estão de acordo com os encontrados por Azzolini (2002), El-Bulk et al. (1997) e Jacomino (1999), que observaram teores crescentes de ácido ascórbico durante a maturação.

O teor de SS é dependente do estádio de maturação no qual o fruto é colhido e geralmente aumenta durante a maturação pela biossíntese ou degradação de polissacarídeos (Chitarra \& Chitarra, 1990).

Houve um pequeno aumento no teor de sólidos solúveis em ambas as variedades ao comparar os frutos no momento da colheita e quando prontos para consumo, porém não ocorreu diferença significativa entre os estádios. Jacomino et al. (2003), também observaram um aumento no teor de SS. A perda de matéria fresca pode contribuir para concentrar os açúcares (Chitarra \& Chitarra, 1990; Tucker, 1993), aumentando o teor de SS.

Os frutos mais verdes apresentaram maior teor de AT em ambas variedades, comprovando a influência do ponto de colheita na qualidade final do fruto. Para a variedade Kumagai os frutos no estádio 1 apresentaram-se 30\% mais ácidos que os do estádio 5, já para 'Paluma', os frutos do estádio 1 apresentaram-se cerca de 50\% mais ácidos que os frutos do estádio 5 .

De forma geral o ponto de colheita influenciou a relação SS/AT, sendo os frutos mais verdes aqueles com menor relação. No estádio 1 de goiabas 'Kumagai', o ratio foi significativamente menor que nos estádio 4 e 5 , indicando que os frutos colhidos no estádio 1, mesmo após o armazenamento de dez dias apresentaram-se mais ácido. Já para os frutos de 'Paluma', o ratio diferenciou os estádios 1, 2 e 3 dos demais, sendo estes os frutos com menor ratio. 


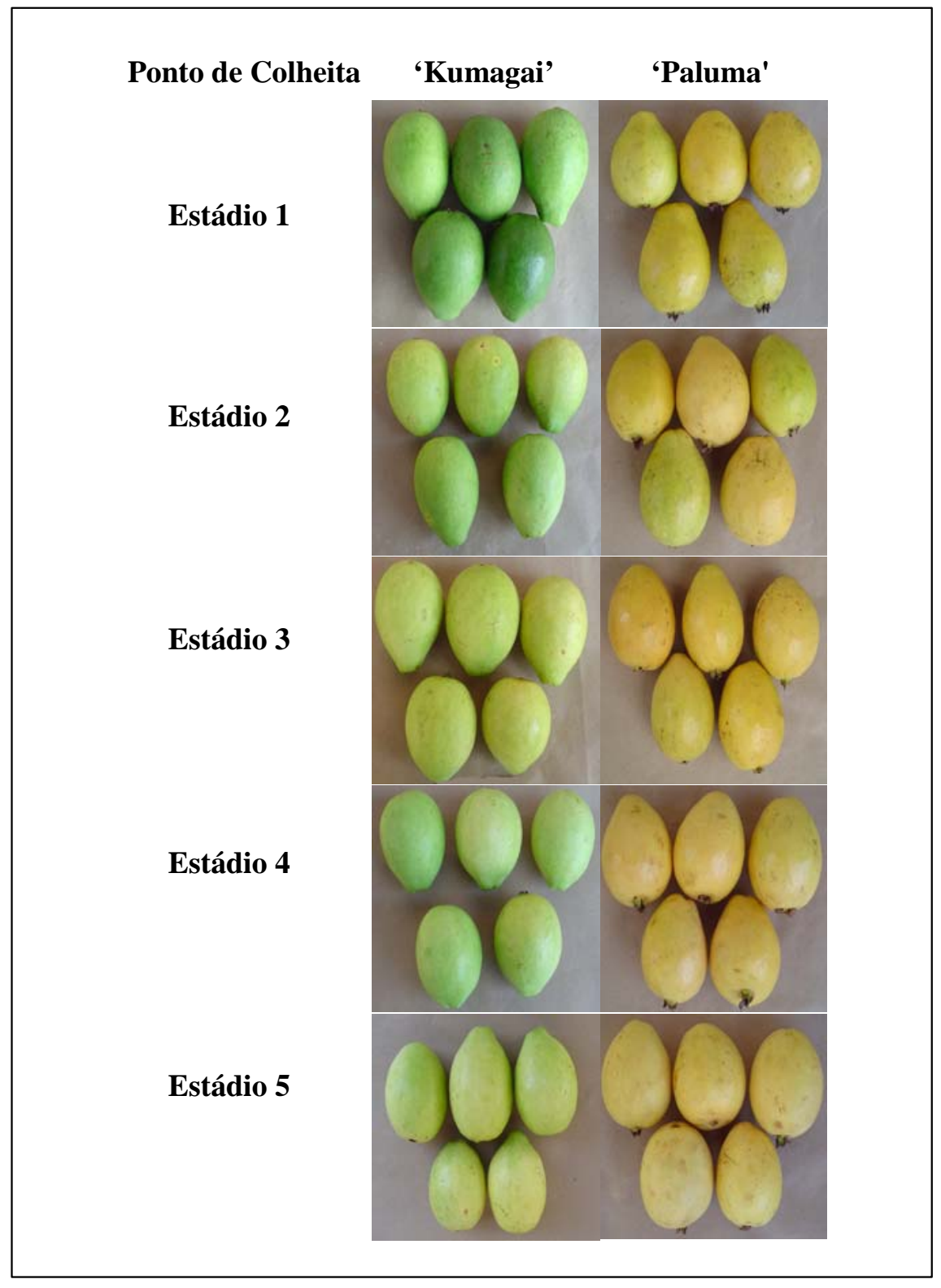

Figura 5- Goiabas 'Kumagai' e 'Paluma' ao final do período comercializável em função do ponto de colheita

$\mathrm{O}$ avanço do processo de amadurecimento torna o fruto mais suscetível ao ataque de patógenos devido à diminuição da resistência da casca e da polpa, decorrentes do amolecimento (Castro \& Sigrist, 1988). O estádio 1, apesar de ter uma coloração ainda verde aos dez dias, apresentou porcentagem de podridão igual a $18 \%$, inviabilizando a comercialização de goiabas 'Kumagai'. 
Em todos os estádios houve perda de matéria fresca ao final do período comercializável, o que acabou afetando a firmeza dos frutos, deixando-os murchos. Os frutos colhidos mais verdes (estádio 1) apresentaram maior perda de matéria fresca do que aqueles colhidos mais maduros em ambas variedades. Segundo Kader (1986), a perda de água em torno de 5 a $10 \%$ da massa fresca, pode tornar o fruto impróprio para a comercialização.

As características físico-químicas indicam qual a concentração dos substratos (ácidos e açúcares) e permitem quantificar a firmeza e cor dos frutos, porém não transmitem o sabor, odor, textura, índices que só são obtidos através da análise sensorial.

$\mathrm{Na}$ figura 6 encontram-se as características sensoriais das variedades Kumagai e Paluma ao final do período comercializável.

O odor é um dos principais atributos utilizado pelo consumidor para aceitação ou rejeição de um produto, sendo este, conseqüência da síntese de numerosos compostos voláteis (Wills et al., 1998). Através do odor foi possível observar que os provadores da variedade Kumagai tiveram menor preferência pelos frutos do estádio 1, pois estes se apresentaram com odor característico, porém muito fraco. Já a análise da variedade Paluma mostrou que os provadores preferiram os frutos do estádio 5, pois estes apresentaram odor característico acentuado.

O sabor é uma sensação complexa que envolve principalmente o sentido do paladar e o aroma do produto. O paladar inclui quatro sensações: doce, salgado, ácido e amargo (Awad, 1993). As melhores notas de sabor foram dadas aos frutos colhidos no estádio 5 para ambas variedades, tendo o lote goiabas mais doces e menos ácidas, assim como pode ser observado nas análises físico-químicas. Os frutos dos demais estádios foram considerados piores, pois se encontraram muito ácidos.

A análise sensorial da textura buscou captar a crocância dos frutos, e apesar de não ter sido encontrada diferença significativa de firmeza entre os 5 estádios de goiabas 'Kumagai', a análise sensorial mostrou diferenças, sendo que os estádios 4 e 5 apresentaram-se crocantes e com a placenta macia, segundo comentários colhidos nos relatórios preenchidos pelos provadores. 
Para 'Paluma', os provadores não conseguiram detectar diferença de textura entre os estádios.

\section{Kumagai}
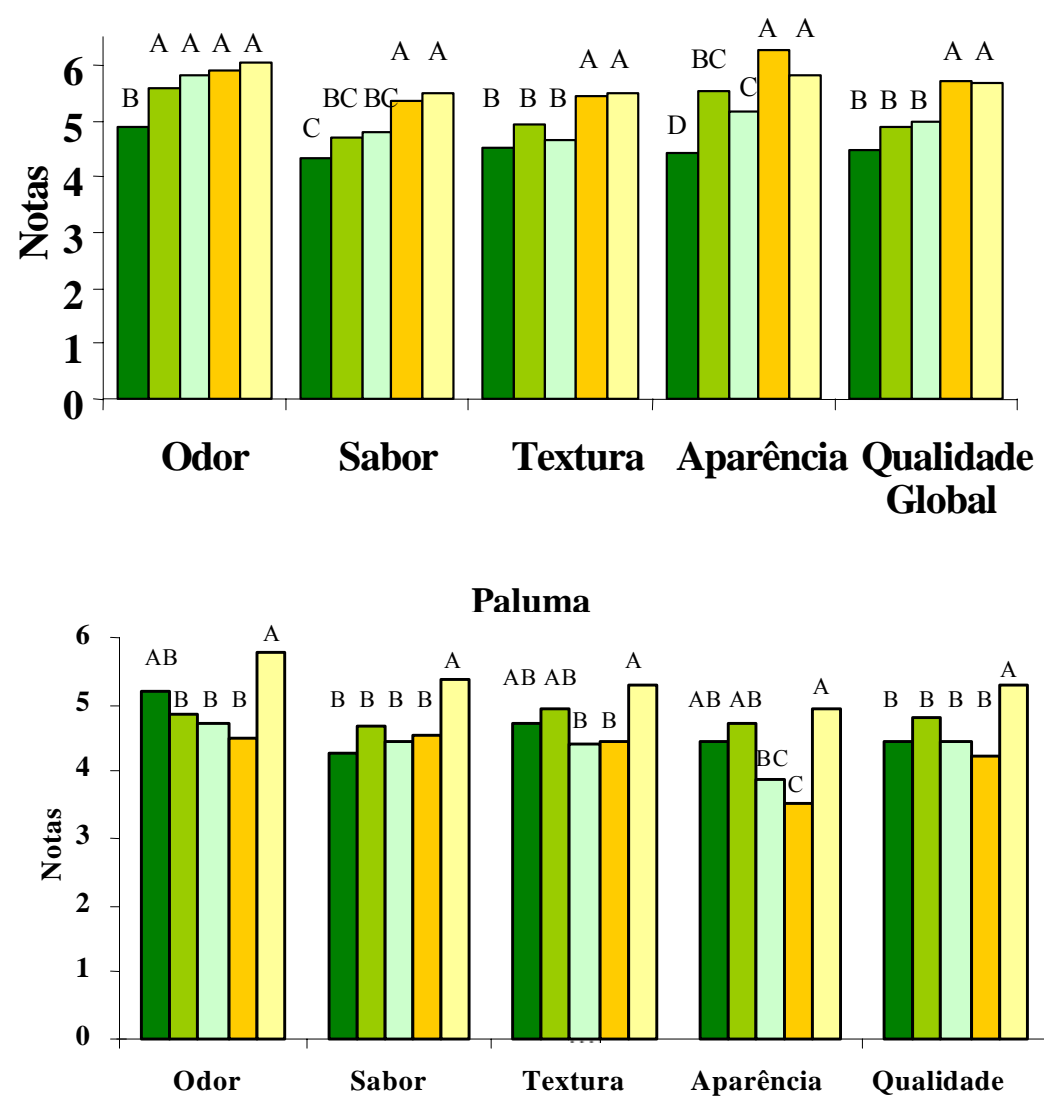

Paluma

\begin{tabular}{lccc}
\hline Legenda & $\begin{array}{c}\text { Estádio de } \\
\text { maturação }\end{array}$ & $\begin{array}{c}\text { Cor da casca no } \\
\text { momento da colheita }\end{array}$ & $\begin{array}{c}\text { Período de } \\
\text { armazenamento } \\
\text { (dias) }\end{array}$ \\
\hline$\square$ & Estádio 1 & Verde escura & 10 \\
$\square$ & Estádio 2 & Quebra da cor verde & 9 \\
$\square$ & Estádio 3 & Início da cor amarela & 6 \\
$\square$ & Estádio 4 & Parcialmente amarela & 5 \\
Estádio 5 & Totalmente amarela & 4 \\
\hline
\end{tabular}

Figura 6- Análise sensorial de goiabas colhidas em cinco estádios de maturação e armazenadas a $25 \pm 2^{\circ} \mathrm{C}$ e $80-90 \%$ UR até o completo amadurecimento (Notas: $1=$ péssimo; $2=$ muito ruim; $3=$ ruim; $4=$ regular; 5 = bom; $6=$ muito bom; $7=$ ótimo). Médias seguidas de mesma letra não diferem entre si pelo teste de Tukey a $5 \%$ de probabilidade 
Em relação à aparência foram avaliados aspectos relacionados à coloração da casca, presença de lesões por danos mecânicos e/ou podridões, brilho e aspecto de frescor. Para 'Kumagai' a melhor nota foi para o estádio 4, pois se apresentou com brilho, coloração parcialmente amarela e com ausência de lesões. A aparência da variedade Paluma mostrou-se melhor no estádio 5, devido ao aspecto de frescor, visto que tal estádio foi submetido à análise sensorial após 1 dia de colhido.

No atributo qualidade global, procurou-se reunir, todos os atributos anteriores. Para as goiabas 'Kumagai', os estádios 4 e 5 foram classificados como melhores que os demais, já para as goiabas 'Paluma' as melhores notas foram atribuídas para o estádio 5.

No geral, isso demonstra que o processo de amadurecimento dos frutos colhidos nos estádios mais verdes não permitiu que estes atingissem a mesma qualidade daqueles colhidos em estádios mais avançados de maturação.

Sendo assim, a colheita de frutos muito verdes só é válida quando a necessidade de conservação em condições ambiente, por longo período, for inevitável. A necessidade de conservação de goiabas colhidas em estádios de maturação mais avançados torna indispensável a implementação de técnicas de conservação que permitam ampliar o período de comercialização.

\subsection{Evolução fisiológica e físico-química de goiabas 'Kumagai' e 'Paluma'durante o amadurecimento}

\subsubsection{Análise fisiológica}

A taxa respiratória e a produção de etileno podem diferir de uma variedade para outra. O acompanhamento da evolução fisiológica e físico-química pós-colheita permite que se atue de forma a escolher o método de conservação mais adequado, assim como permite decidir qual o melhor momento para a colheita, visando melhor qualidade final de tais frutos. 
- Atividade respiratória

Variedade Kumagai

A taxa respiratória variou do estádio 1 para os demais, porém os estádios 2 e 3 não apresentaram diferenças entre si $(\mathrm{p}<0,05)$.

Observou-se aumento da atividade respiratória no decorrer do armazenamento para todos os estádios de maturação. A atividade máxima ocorreu aos 11; 11 e 13 dias de armazenamento, para os frutos colhidos nos estádios 3, 2 e 1, respectivamente (Figura 7).

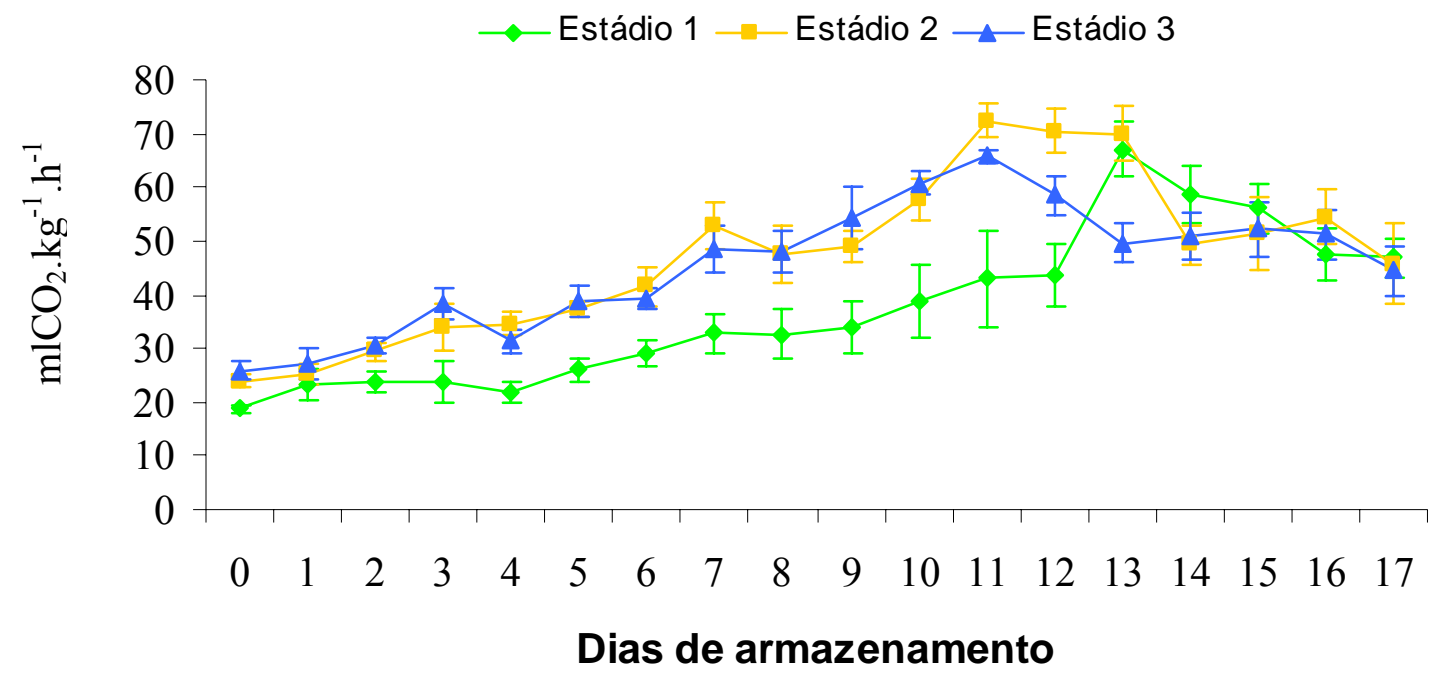

Figura 7- Atividade respiratória de goiabas 'Kumagai' colhidas em diferentes estádios de maturação e armazenadas a $25 \pm 2^{\circ} \mathrm{C}$ e 80-90\%UR. (Estádios de maturação 1, 2 e 3, frutos colhidos com cor da casca verde-escura, verdeclara e amarela, respectivamente). As barras verticais indicam o erro

As goiabas apresentaram atividade respiratória mínima no tempo 0 , com valores de 18,$20 ; 23,40$ e $25,20 \mathrm{mlCO} 2 \cdot \mathrm{kg}^{-1} \cdot \mathrm{h}^{-1}$, respectivamente para os estádios 1,2 e 3 . A respiração aumentou gradualmente até o décimo segundo, nono e sétimo dias após a colheita para os estádios 1, 2 e 3 respectivamente, a partir dos quais foi possível observar um aumento acentuado da taxa respiratória, seguida de decréscimo para todos os estádios de maturação. Os valores máximos obtidos foram de 67,72 e $65 \mathrm{mlCO}_{2} \cdot \mathrm{kg}^{-1} \cdot \mathrm{h}^{-}$ 
1, para os estádios 1, 2 e 3 (Figura 7). Esses valores são pouco superiores aos encontrados por Botelho (1996), para goiabas 'Kumagai', segundo o autor, a atividade máxima foi de aproximadamente $55 \mathrm{mlCO} 2 \cdot \mathrm{kg}^{-1} \cdot \mathrm{h}^{-1}$ sete dias após a colheita. Oliveira (1996), também em goiabas 'Kumagai' observou o pico respiratório aos nove dias após a colheita, com valor de $51,38 \mathrm{mlCO}_{2} \cdot \mathrm{kg}^{-1} \cdot \mathrm{h}^{-1}$.

Variedade Paluma

Observou-se pequeno aumento da atividade respiratória no decorrer do armazenamento para todos os estádios de maturação. A atividade máxima ocorreu aos 9 dias de armazenamento, para todos os estádios (Figura 8).

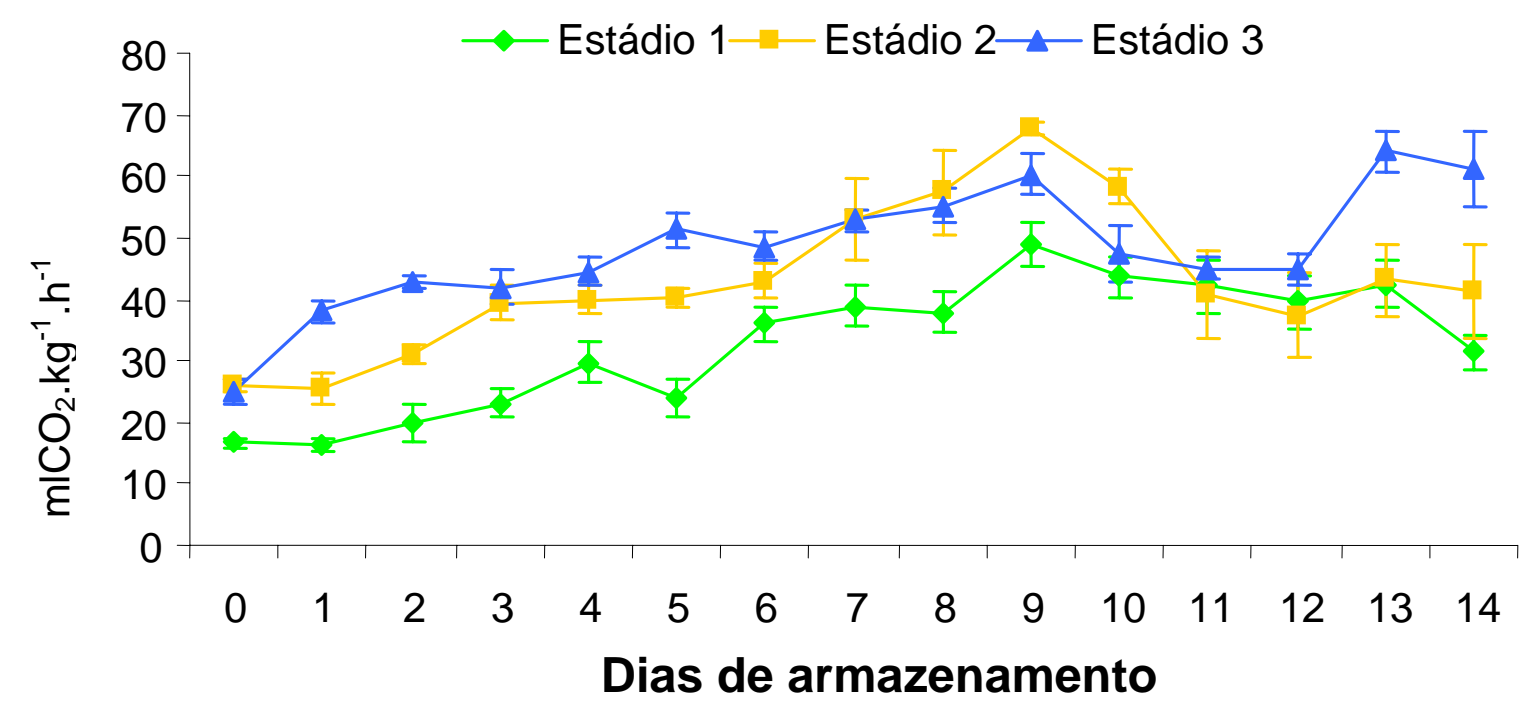

Figura 8- Atividade respiratória de goiabas 'Paluma' colhidas em diferentes estádios de maturação e armazenadas a $25 \pm 2^{\circ} \mathrm{C}$ e $80-90 \%$ UR. (Estádios de maturação 1,2 e 3, frutos colhidos com cor da casca verde-escura, verde-clara e amarela, respectivamente). As barras verticais indicam o erro

Os estádios 2 e 3 apresentaram atividade respiratória semelhantes e apenas o estádio 1 diferiu dos demais. Os mínimos valores da atividade respiratória foram 15, 25 e 24 $\mathrm{mlCO}_{2} \cdot \mathrm{kg}^{-1} \cdot \mathrm{h}^{-1}$, respectivamente para os estádios 1,2 e 3 . A respiração apresentou aumento constante com atividade máxima aos nove dias de armazenamento. $\mathrm{O}$ aumento 
da taxa respiratória nos tempos 13 e 14 do estádio 3 são devido a presença de podridões nos frutos.

Os valores máximos obtidos foram de 48,60 mlCO $2 \cdot \mathrm{kg}^{-1} \cdot \mathrm{h}^{-1}$ para o estádio $1,67,60$ $\mathrm{mlCO}_{2} \cdot \mathrm{kg}^{-1} \cdot \mathrm{h}^{-1}$ para o estádio 2 e $60,00 \mathrm{mlCO} \cdot \mathrm{kg}^{-1} \cdot \mathrm{h}^{-1}$ para o estádio 3. Esses valores são superiores aos obtidos por Lima et al. (1998), estes observaram que goiabas 'Pedro Sato' que frutos colhidos nos estádios verde e "de vez" apresentaram máxima atividade respiratória de $17,46 \mathrm{mlCO}_{2} \cdot \mathrm{kg}^{-1} \cdot \mathrm{h}^{-1}$, quatro dias após a colheita e $12,30 \mathrm{mlCO} 2 \cdot \mathrm{kg}^{-1} \cdot \mathrm{h}^{-1}$ três dias após a colheita, respectivamente. Mercado-Silva et al. (1998), verificaram aumento acentuado da atividade respiratória em goiabas 'Media China', com pico ocorrendo entre quatro e cinco dias após a colheita, em função do estádio de maturação e da época de colheita. Azzolini (2002), observou para goiaba 'Pedro Sato', aumento gradual da atividade respiratória, com valores máximos de $85,00 \mathrm{mlCO} 2 \cdot \mathrm{kg}^{-1} \cdot \mathrm{h}^{-1}$ para o estádio 1 e de $74 \mathrm{mlCO}_{2} \cdot \mathrm{kg}^{-1} \cdot \mathrm{h}^{-1}$ para os estádios 2 e 3 aos 11,10 e 8 dias após a colheita.

O aumento da respiração durante o amadurecimento de frutos climatéricos é entendido como uma resposta homeostática da mitocôndria em uma tentativa de compensar os danos causados à célula em função do aumento do metabolismo decorrente da produção autocatalítica do etileno (Romani, 1984). A diminuição da respiração na fase considerada pós-climatérica representa a perda da capacidade homeostática da mitocôndria, tornando assim predominante os processos de senescência.

Segundo Wills et al. (1998), a intensidade respiratória é um dos fatores determinantes na longevidade das frutas após a colheita, considerando que a respiração é um processo oxidativo das substâncias de reserva, levando o órgão a senescência.

No geral, os estádios 2 e 3 apresentaram semelhanças na atividade respiratória e o estádio 1 apresentou-se inferior aos demais em ambas as variedades. O pico respiratório ocorreu entre 10 e 13 dias para a variedade Kumagai e no nono dia de armazenamento para a variedade Paluma. 
- Produção de etileno

Variedade Kumagai

A produção de etileno apresentou um pico em todos os estádios de maturação. $\mathrm{O}$ estádio 1apresentou valores de produção de etileno inferiores aos estádios 2 e 3, sendo que esses dois apresentaram-se semelhantes $(\mathrm{p}<0,05)$.

Os menores valores encontrados foram 0,$31 ; 0,36$ e $0,58 \mu \mathrm{CO}_{2} \cdot \mathrm{kg}^{-1} \cdot \mathrm{h}^{-1}$ para os estádios 1, 2 e 3, respectivamente. Inicialmente os valores mostraram-se estáveis até o oitavo dia, com pico característico aos 9 dias de armazenamento, seguido de queda.Os valores máximos foram de 2,37; 2,95 e 3,16 $\mu \mathrm{lCO}_{2} \cdot \mathrm{kg}^{-1} \cdot \mathrm{h}^{-1}$ para os estádios 1,2 e 3, respectivamente. $\mathrm{O}$ aumento da produção de etileno a partir do $15^{\circ}$ dia para os estádios 2 e 3 são devido a ocorrência de podridões.

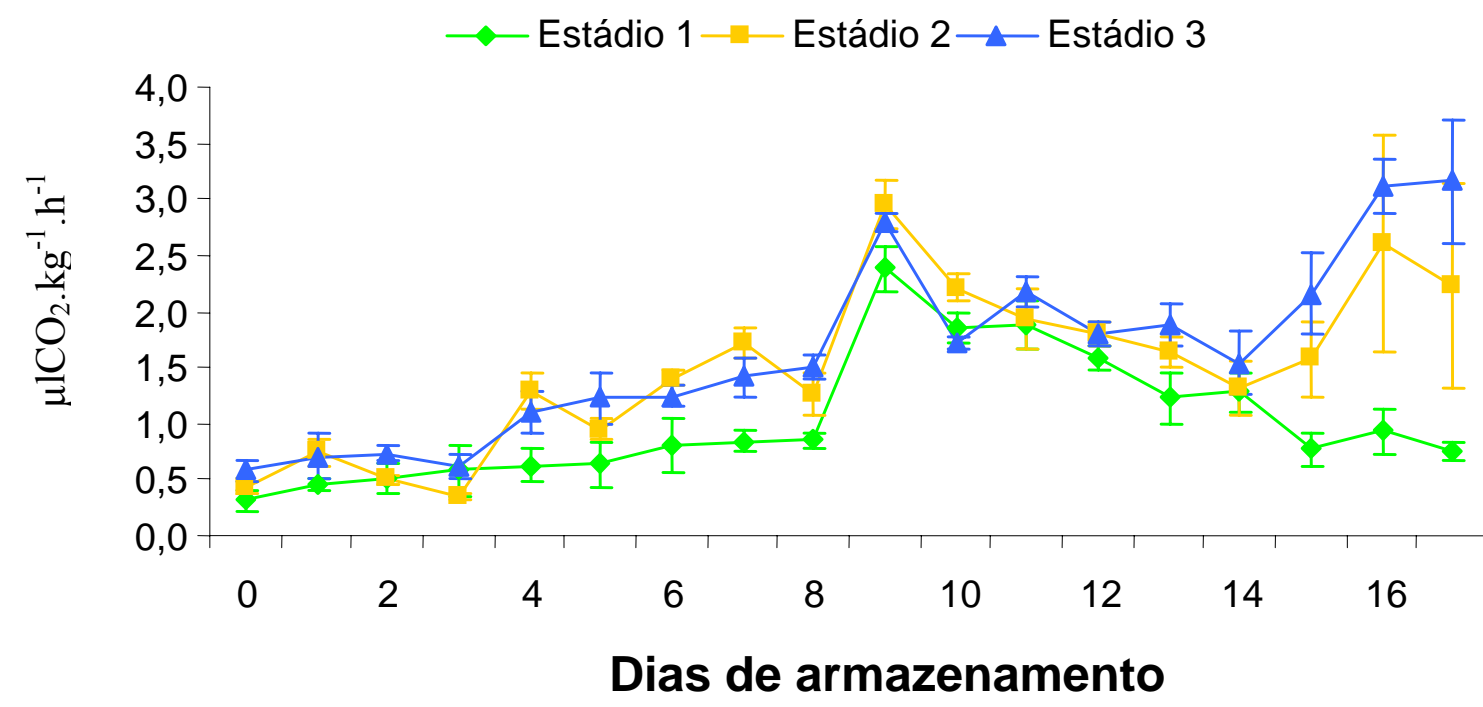

Figura 9- Produção de etileno em goiabas 'Kumagai' colhidas em três estádios de maturação e armazenadas a $25 \pm 1^{\circ} \mathrm{C}$ e $80-90 \%$ UR. (Estádio de maturação 1,2 e 3, frutos colhidos com cor da casca verde-escura, verde-clara e amarela, respectivamente). As barras verticais indicam o erro

A produção de etileno apresentou valores semelhantes aos obtidos por Akamine \& Goo (1979) para as variedades White guava e Purple strawberry guava. 
A menor produção de etileno nos estádios 1 e 2, possivelmente, seja devido a menor sensibilidade dos frutos a este fitohormônio, em função do estádio de desenvolvimento do fruto (Yang, 1985). A menor sensibilidade está relacionada com o menor número de sítios receptores presentes nos tecidos. Segundo Yen et al. (1995), o número de receptores aumenta durante o amadurecimento, permitindo o aumento da ação do etileno e a contínua produção autocatalítica.

Variedade Paluma

Os estádios 1, 2 e 3 apresentaram comportamentos distintos quanto a produção de etileno nos primeiros quatro dias após a colheita. O estádio 1produziu pouco etileno (entre 0,0 e $0,28 \mu \mathrm{lC}_{2} \mathrm{H}_{4} \cdot \mathrm{kg}^{-1} \cdot \mathrm{h}^{-1}$ ), enquanto os frutos do estádio 3 apresentaram produção de etileno de 1,51 a $3,04 \mu \mathrm{lC}_{2} \mathrm{H}_{4} \cdot \mathrm{kg}^{-1} \cdot \mathrm{h}^{-1}$. Os frutos do estádio 2 assumiram valores intermediários, apresentando aumento significativo na produção de etileno a partir do quinto dia após a colheita, com produção máxima bem definida no sétimo dia $(4,80$ $\left.\mu \mathrm{lCO}_{2} \cdot \mathrm{kg}^{-1} \cdot \mathrm{h}^{-1}\right)$. Já os frutos dos estádios 1 e 3 não apresentaram pico climatérico típico.

$\multimap$ Estádio 1—-Estádio 2־ Estádio 3

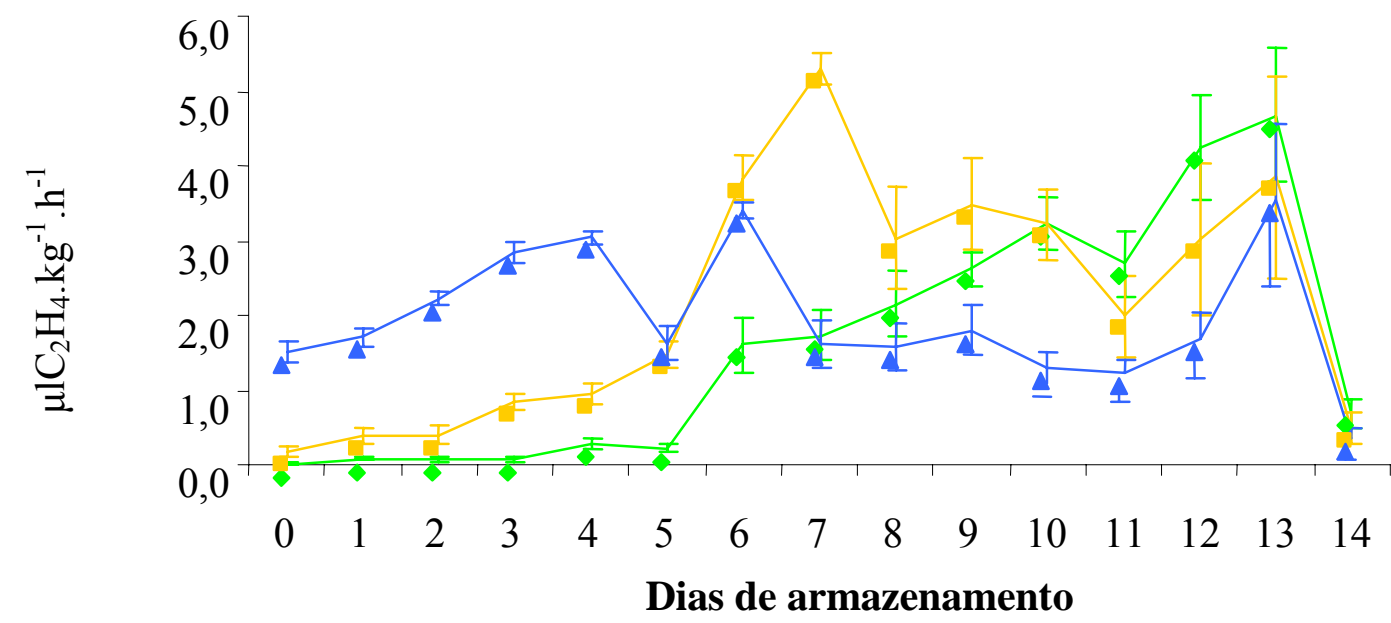

Figura 10- Produção de etileno em goiabas 'Paluma' colhidas em três estádios de maturação e armazenadas a $25+1{ }^{\circ} \mathrm{C}$ e $80-90 \%$ UR. (Estádio de maturação 1,2 e 3 , frutos colhidos com cor da casca verde-escura, verde-clara e amarela, respectivamente). As barras verticais indicam o erro 
A produção de etileno apresentou valores semelhantes aos obtidos por Akamine \& Goo (1979). Azzolini (2002), observou pico de produção de etileno aos 9 dias após a colheita para os estádios 1 e 2 e aos 8 dias após a colheita para o estádio 3, com produção máxima semelhante.

\subsubsection{Análise físico-química: transformações físico-químicas e a relação com a produção de etileno.}

O amadurecimento é uma das fases do desenvolvimento dos frutos, na qual ocorre uma seqüência integrada de transformações na textura, na coloração, no aroma, na acidez, entre outras mudanças fisiológicas e bioquímicas, transformando um fruto fisiologicamente maturo, porém não comestível, em um fruto palatável e visualmente atrativo. Em frutos climatéricos, essas mudanças são reguladas pelo aumento da produção autocatalítica do etileno (Giovanoni, 2001; Mattoo \& Suttle, 1991; Tucker, 1993; Yang, 1985). Genes que controlam as mudanças físico-químicas são ativados com o aumento da produção de etileno (Oiteker \& Yang, 1995).

- Firmeza da polpa

As duas variedades apresentaram intensa perda de firmeza acompanhada de um aumento gradual da produção de etileno. Porém a máxima produção de etileno coincidiu com o período que a perda de firmeza tornou-se praticamente estável (Figura 11). Apenas o estádio 3 da variedade Paluma apresentou queda da firmeza da polpa até o quarto dia, os demais estádios de ambas variedades decaíram nos primeiros seis dias. Esses dados são semelhantes aos obtidos por Azzolini (2002) para goiabas 'Pedro Sato'. 


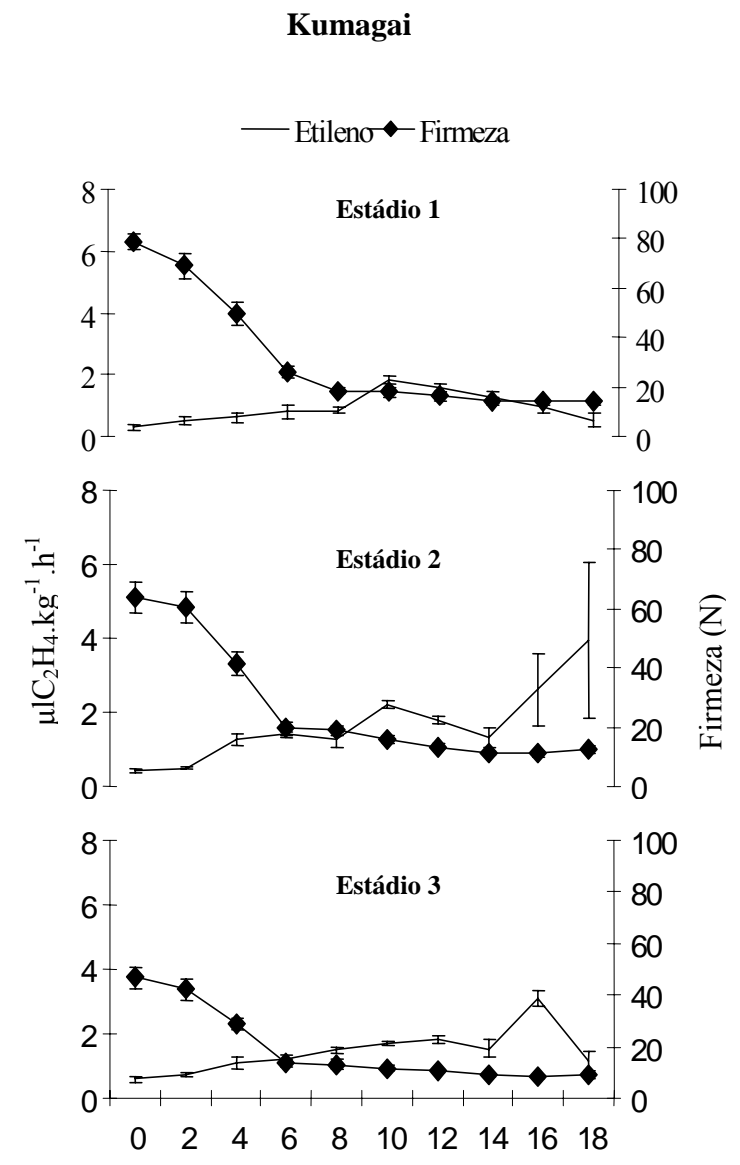

Dias de Armazenamento
Paluma
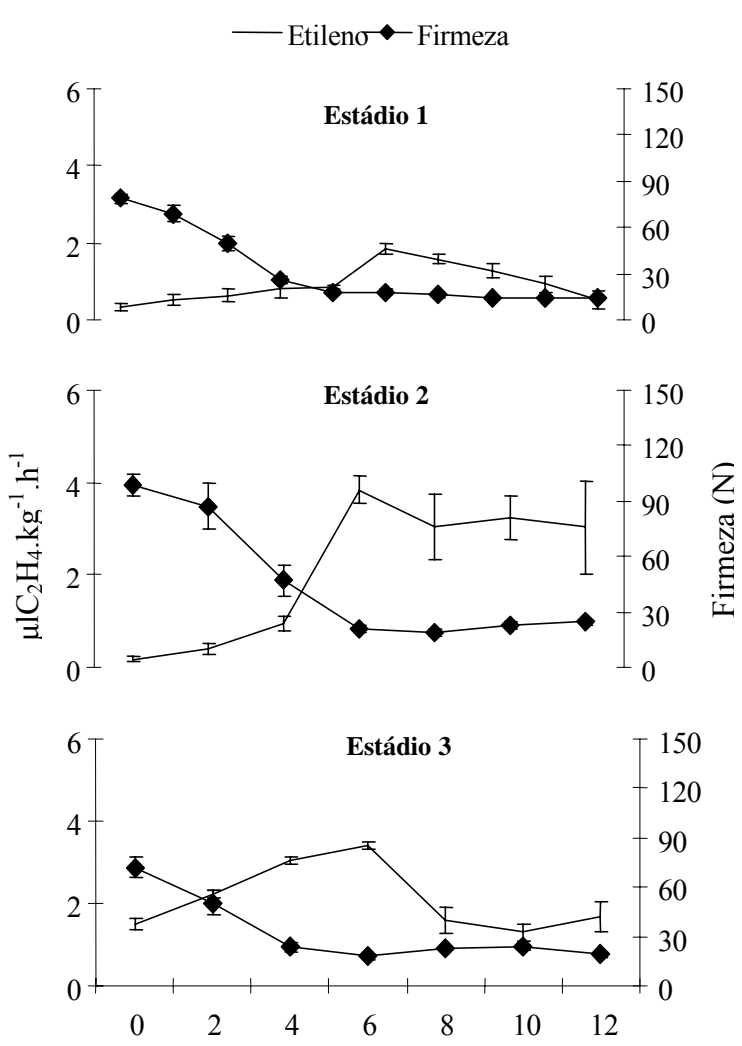

Dias de Armazenamento

Figura 11- Produção de etileno e firmeza da polpa de goiabas colhidas em diferentes estádios de maturação e armazenadas a $25 \pm 1^{\circ} \mathrm{C}$ e $80-90 \%$ UR. (Estádio de maturação 1, 2 e 3, frutos colhidos com cor da casca verde-escura, verde-clara e amarela, respectivamente)

A perda de firmeza é um processo decorrente, principalmente, da degradação da parede celular pelas enzimas pectinolíticas. Em goiabas 'Pedro Sato', Xisto (2002) observou que a atividade da enzima pectinametilesterase (PME) aumenta durante o armazenamento dos frutos, enquanto a atividade da enzima poligalacturonase (PG) diminui. Carvalho (1994), também observou aumento da atividade da enzima PME em goiabas 'Kumagai' armazenadas sob refrigeração discordando dos resultados obtidos por El-Zoghbi (1994), que observou decréscimo da atividade da PME durante o amadurecimento em goiabas colhidas em diferentes estádios de maturação. 
Segundo Leliévre et al. (1997), na maioria dos casos a síntese de enzimas que atuam na degradação da parede celular, principalmente PME e PG, são dependentes da ação do etileno. Gerasopoulos \& Richardon (1996), verificaram que $0,1 \mu 1.1^{-1}$ de etileno foi capaz de induzir o amolecimento, porém não atuou em outros aspectos do amadurecimento.

A alta sensibilidade ao etileno, apresentada pelo processo de amolecimento, pode justificar a intensa perda de firmeza ocorrida nos primeiros dias de armazenamento das goiabas 'Kumagai' e 'Paluma', independente do pico climatérico.

- Cor da casca

Em goiabas 'Kumagai', os três estádios de maturação comportaram-se de forma semelhante. Os frutos de 'Kumagai' apresentaram uma lenta diminuição do ângulo de cor da casca durante todo o período de armazenamento. Já os frutos da variedade Paluma apresentaram diminuição acentuada nos primeiros dias (entre 4 e 6 dias de armazenamento).

A intensa mudança da coloração da casca ocorreu antes do pico de etileno, tal transformação está intimamente ligada a biossíntese de etileno, pois este promove o aumento da atividade das enzimas clorofilases responsáveis pela degradação da clorofila e induz a síntese de novas enzimas responsáveis pela biossíntese de carotenóides (Wills et al., 1998).

Em goiabas 'Kumagai', níveis iniciais de $0,3 \mu \mathrm{lC}_{2} \mathrm{H}_{4} \cdot \mathrm{kg}^{-1} \cdot \mathrm{h}^{-1}$ desencadearam o processo de mudança de coloração. Já para goiaba 'Paluma', níveis baixos como 0,02 $\mu \mathrm{lC}_{2} \mathrm{H}_{4} \cdot \mathrm{kg}^{-1} \cdot \mathrm{h}^{-1}$ foram suficientes para iniciar o processo de alteração da coloração. Abeles et al. et al. (1992) reporta que a concentração de $0,01 \mu 11^{-1}$ representa a concentração mínima de etileno capaz de promover uma resposta fisiológica, o que explica a mudança da coloração em goiabas 'Kumagai' e 'Paluma' mesmo com baixas concentrações de etileno. 


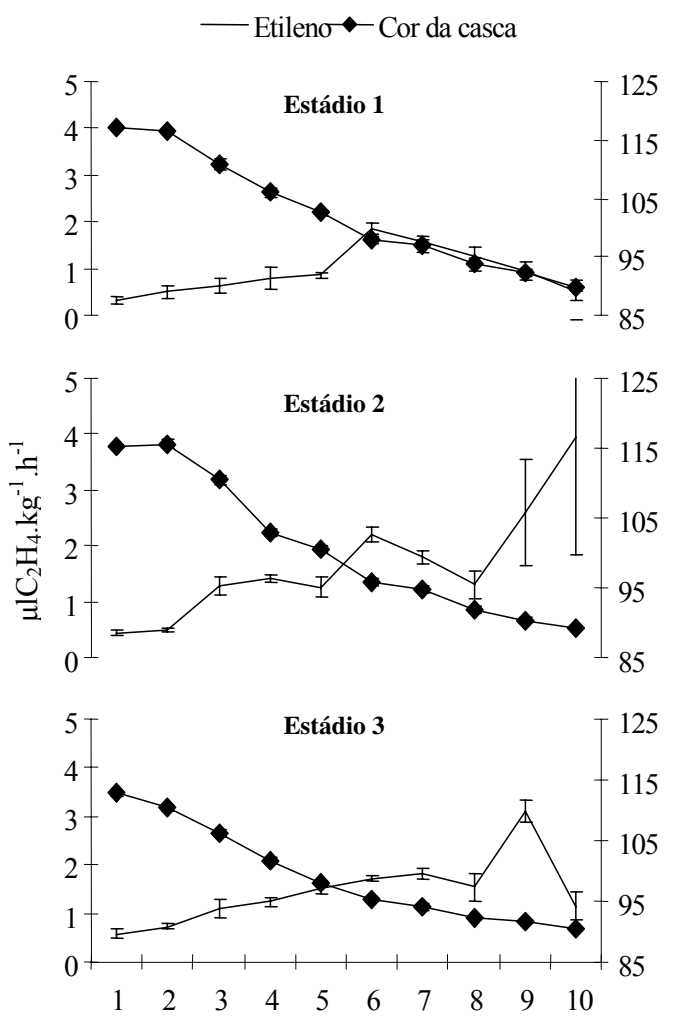

Dias de Armazenamento

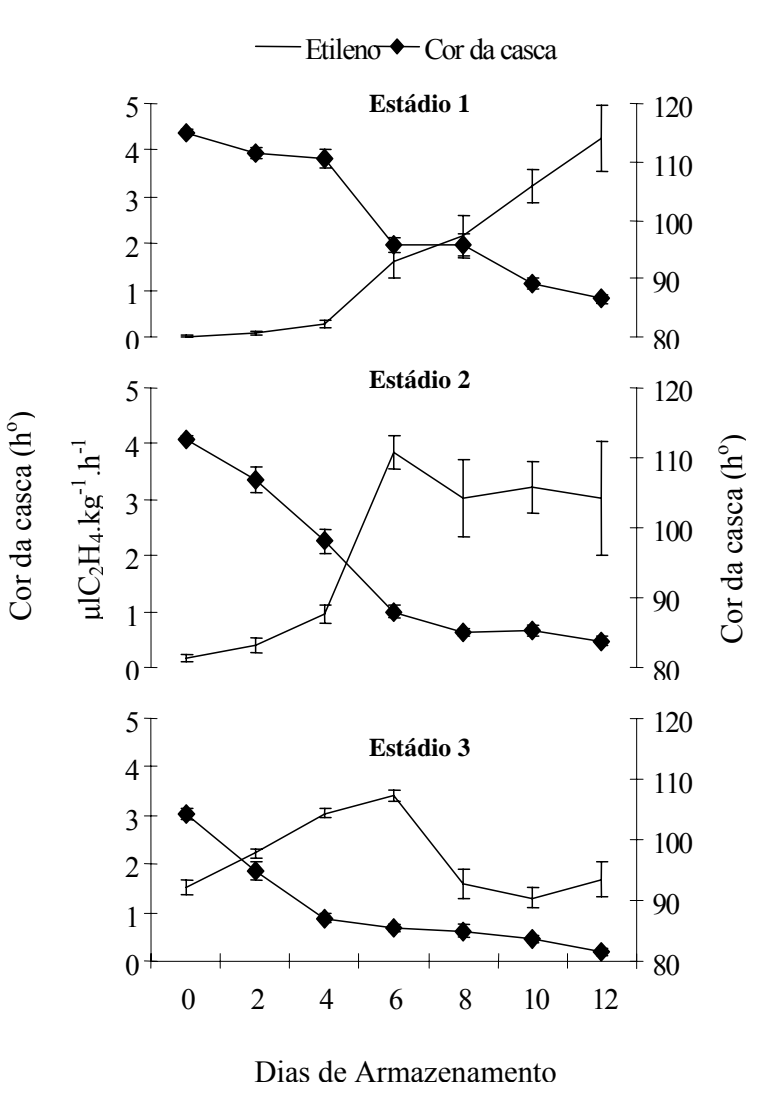

Figura 12- Produção de etileno e cor da casca em goiabas colhidas em diferentes estádios de maturação e armazenadas a $25 \pm 1^{\circ} \mathrm{C}$ e $80-90 \%$ UR. (Estádio de maturação 1,2 e 3 , frutos colhidos com cor $\overline{d a}$ casca verde-escura, verde-clara e amarela, respectivamente)

- Cor da polpa

O croma foi constantemente crescente para todos os estádios de maturação (Figura 13). A variável cor da polpa aumentou conforme o aumento na produção de etileno. No estádio 3, mesmo após uma queda na produção de etileno, a partir do oitavo dia de armazenamento, pode-se observar que continuou havendo aumento no croma, porém em taxas menores que no início do armazenamento.

O licopeno é um dos principais pigmentos responsáveis pela coloração da polpa em goiabas do tipo vermelha (Cross, 1987), sendo que a biossíntese desse pigmento está intimamente ligada a produção de etileno (Oller et al., 1991), o que pode ser confirmado ao observar o comportamento semelhante entre a curva de produção de etileno e a curva de mudança da coloração da polpa em goiabas 'Paluma'. 


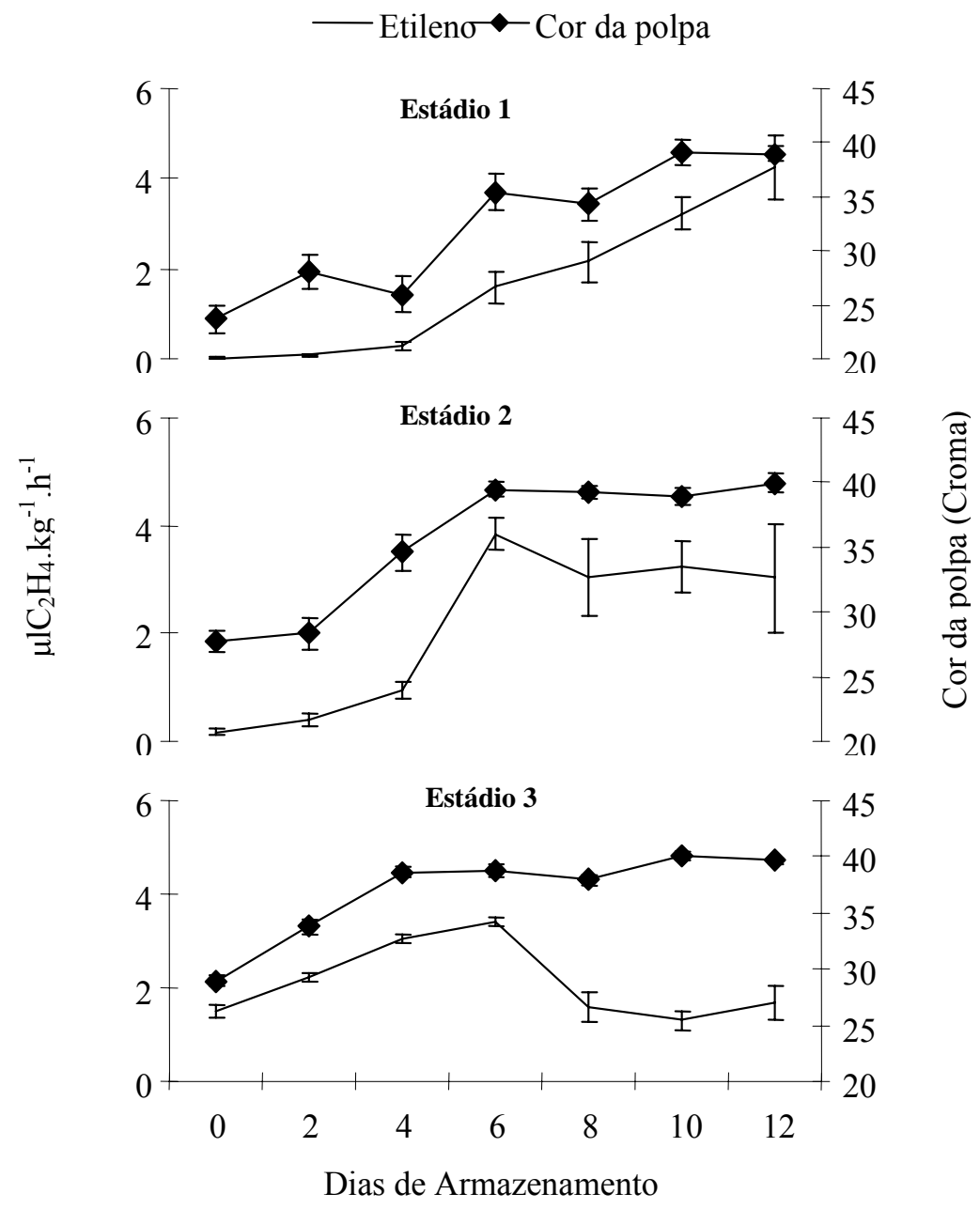

Figura 13- Produção de etileno e cor da polpa em goiabas 'Paluma' colhidas em diferentes estádios de maturação e armazenadas a $25 \pm 1^{\circ} \mathrm{C}$ e $80-90 \%$ UR. (Estádio de maturação 1, 2 e 3, frutos colhidos com cor da casca verdeescura, verde-clara e amarela, respectivamente)

- Teor de ácido ascórbico

$\mathrm{Na}$ variedade Kumagai o teor de ácido ascórbico aumentou durante o armazenamento, até o completo amadurecimento, indicando que houve síntese constante deste ácido (Figura 14). Jacomino et al. (2003), também observaram aumento do teor de ácido ascórbico em goiabas 'Kumagai' durante o armazenamento. Segundo MercadoSilva et al. (1998) e Teaotia et al. (1970) o aumento do teor de ácido ascórbico pode ser resultado da produção de precursores do ácido ascórbico na respiração. Os teores de ácido ascórbico variaram de 95 a $160 \mathrm{mg}$ de ácido ascórbico. $100 \mathrm{~g}$ de polpa ${ }^{-1}$. 
Já na variedade Paluma observou-se pequeno aumento no teor de ácido ascórbico no início do armazenamento, com posterior tendência de diminuição durante o armazenamento (Figura 14).

O decréscimo do conteúdo de ácido ascórbico pode indicar senescência, pois segundo Esteves et al. (1984), o teor de ácido ascórbico aumenta durante o amadurecimento e decresce rapidamente durante a senescência.

Os teores de ácido ascórbico variaram de 60 a $105 \mathrm{mg}$ de ácido ascórbico. $100 \mathrm{~g}$ de polpa $^{-1}$, resultados semelhantes aos encontrados por Xisto (2002) e por Ojeda (2001) para goiabas 'Pedro Sato'.

O pequeno aumento observado no teor de ácido ascórbico antecedeu a máxima produção de etileno em todos os estádios de maturação, diminuindo no período de maior produção de etileno e maior respiração. 
Kumagai

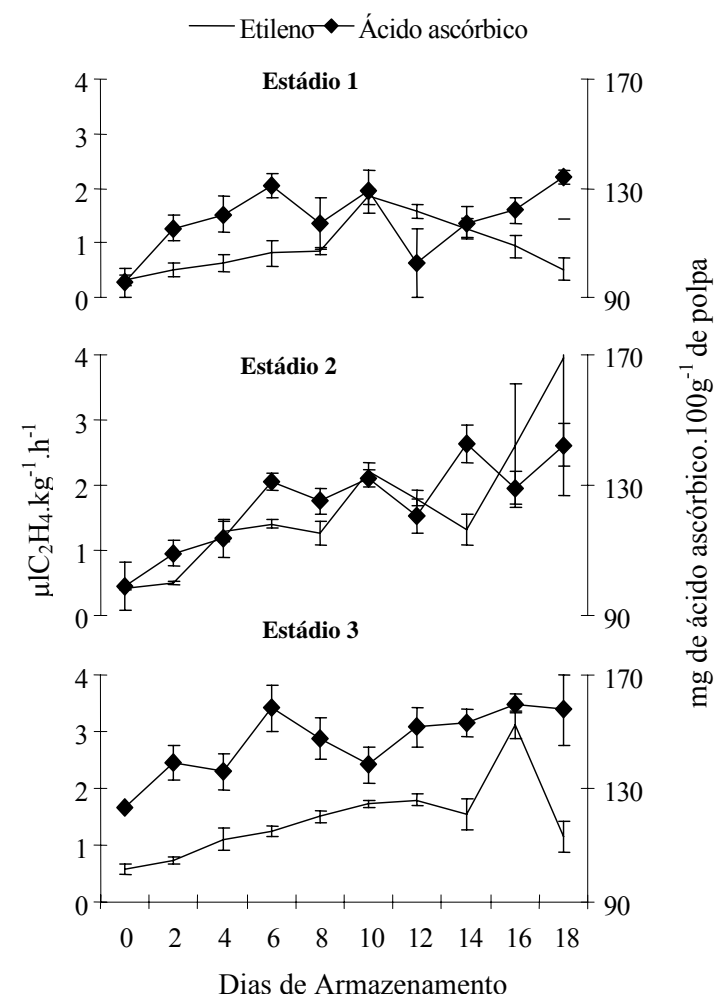

Paluma

49

Etileno Ácido ascórbico

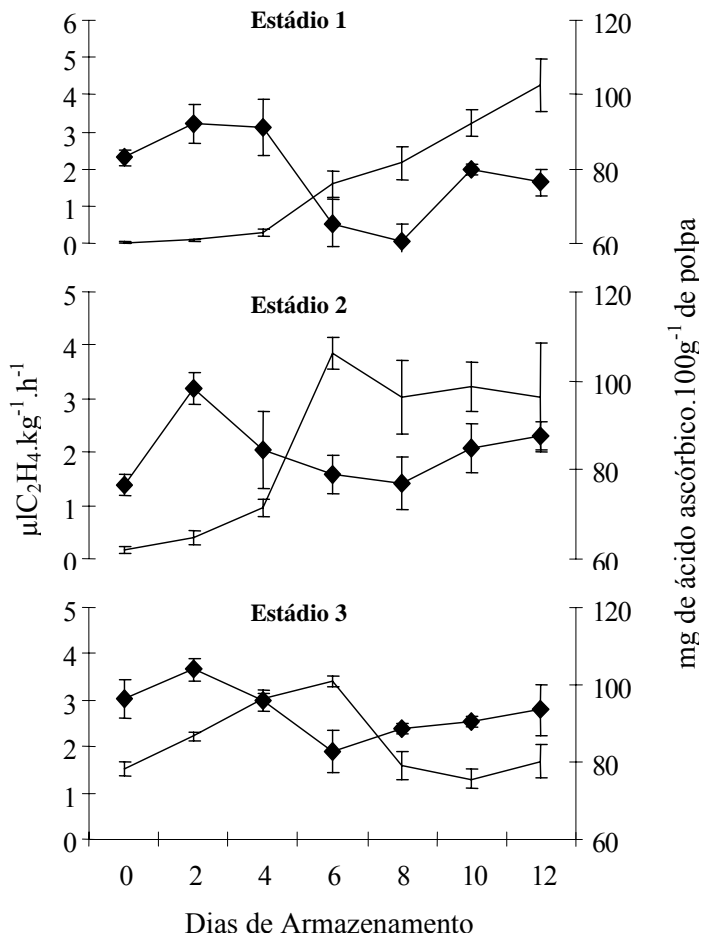

Figura 14- Produção de etileno e teor de ácido ascórbico em goiabas colhidas em diferentes estádios de maturação e armazenadas a $25 \pm 1^{\circ} \mathrm{C}$ e $80-90 \%$ UR. (Estádio de maturação 1,2 e 3 , frutos colhidos com cor da casca verde-escura, verde-clara e amarela, respectivamente)

- Sólidos solúveis

O teor de sólidos solúveis apresentou leve aumento no início do armazenamento, seguido de decréscimo para ambas as variedades, mas especialmente para a variedade Kumagai (Figura 15). Esses resultados estão de acordo com Jacomino (1999), que também observou redução do teor de SS para esta variedade, durante o armazenamento refrigerado.

A maior porcentagem dos sólidos solúveis são os açúcares, que são consumidos durante o amadurecimento no processo respiratório.

A variedade Paluma também não apresentou grande variação no teor de SS, assim como Pivetta et al. (1992), que não verificaram mudanças no teor de sólidos solúveis em função do ponto de colheita. O mesmo foi observado por Azzolini (2002) para goiabas 'Pedro Sato'. 
Segundo Rhodes (1980), os frutos que não contêm açúcares de reserva, não apresentam significativos incrementos nos teores de açúcares e conseqüentemente no teor de sólidos solúveis, durante o amadurecimento.

Para goiabas 'Kumagai' e 'Paluma', não foi observada forte relação entre a produção de etileno e o teor de SS (Figura 15), corroborando para os resultados obtidos por Azzolini (2002), em goiabas 'Pedro Sato'.

\section{a) Acidez titulável}

Em ambas as variedades observou-se pequeno aumento no teor da acidez com posterior diminuição (Figura 16). Dados semelhantes foram obtidos por Azzolini (2002),

para 3 estádios de maturação de goiabas 'Pedro Sato', assim como Xisto (2002), em goiabas 'Pedro Sato' tratadas ou não com cálcio e Gianonni (2000), em goiabas 'Kumagai', sob refrigeração. Observou-se também, que os frutos colhidos mais verdes apresentaram-se mais ácidos.

Verificou-se uma tendência de diminuição do teor de acidez no período de máxima produção de etileno, principalmente na variedade Paluma. A diminuição nos teores de acidez durante o amadurecimento é um processo esperado, em função da oxidação dos ácidos orgânicos na respiração (Awad, 1993). 

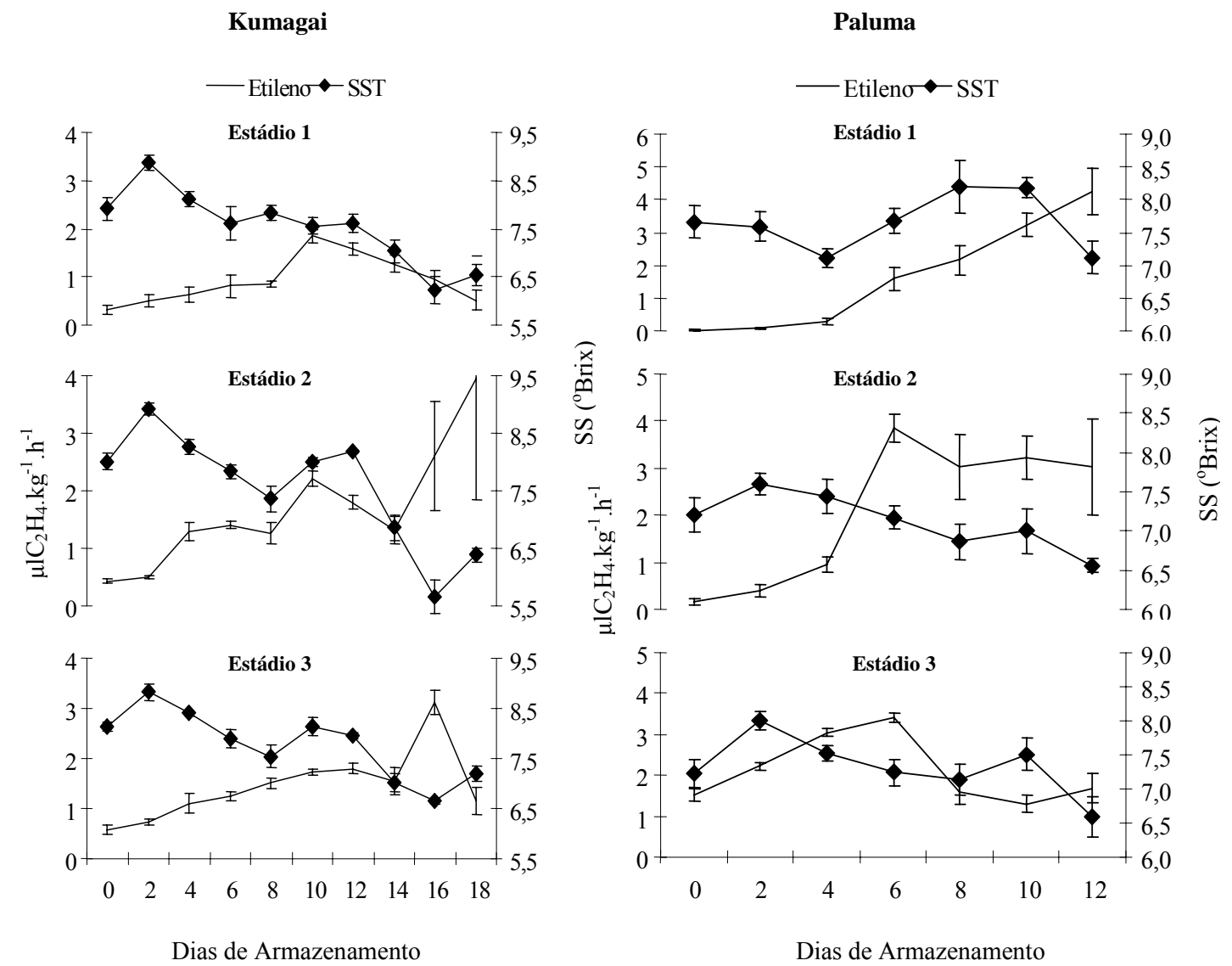

Figura 15- Produção de etileno e teor de sólidos solúveis em goiabas em diferentes estádios de maturação e armazenadas a $25 \pm 1^{\circ} \mathrm{C}$ e $80-90 \%$ UR. (Estádio de maturação 1, 2 e 3, frutos colhidos com cor da casca verde-escura, verde-clara e amarela, respectivamente) 

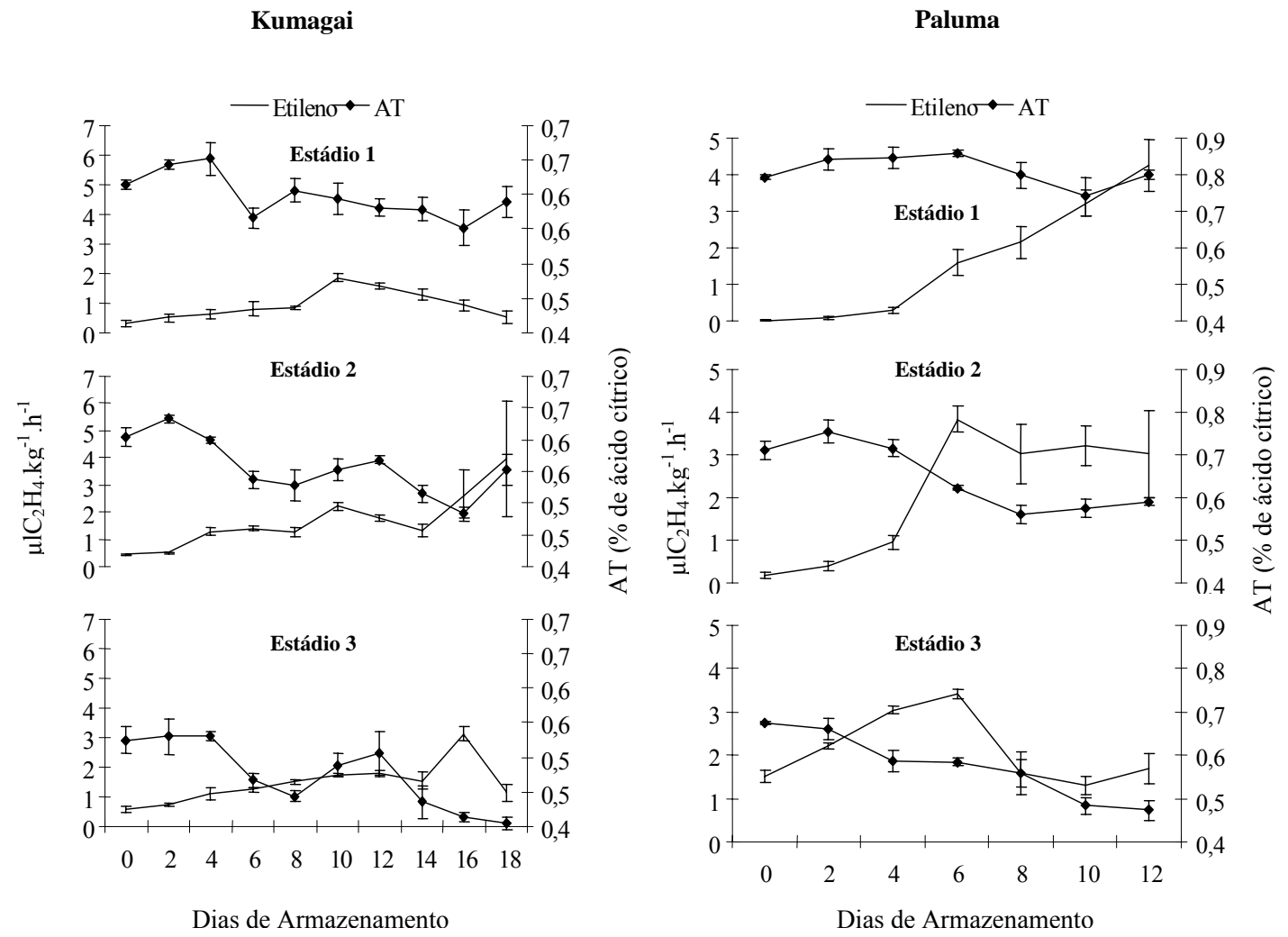

Figura 16- Produção de etileno e teor de acidez titulável em goiabas colhidas em diferentes estádios de maturação e armazenadas a $25+1^{\circ} \mathrm{C}$ e $80-90 \%$ UR. (Estádio de maturação 1,2 e 3 , frutos colhidos com cor da casca verde-escura, verde-clara e amarela, respectivamente)

O completo amadurecimento de um fruto ocorre quando este atinge a máxima qualidade comestível (Giovannoni, 2001; Lelièvre et al., 1997; Tucker, 1993; Watada et al., 1984; Wills et al., 1998). Com base neste conceito, o completo amadurecimento dos frutos colhidos nos estádios 3, 2 e 1 da cultivar Kumagai se deu aos 6, 9 e 10 dias, respectivamente, já para a cultivar Paluma o completo amadurecimento ocorreu aos 3, 4 e 6 dias, respectivamente para os mesmos estádios. Após esse período, os frutos apresentaram sabor desagradável e baixa firmeza, além da baixa qualidade na aparência. $\mathrm{O}$ aspecto de sobremaduro foi intensificado pela perda da coloração da casca e pelo aspecto gelatinoso da região placentária.

$\mathrm{Na}$ maioria dos frutos climatéricos, o pico respiratório e a produção de etileno correspondem ao período de amadurecimento do fruto. Entretanto, verificou-se que em 
goiabas 'Kumagai' e 'Paluma', o pico climatérico ocorreu após o completo amadurecimento dos frutos.

A máxima atividade respiratória ocorreu quando os frutos apresentavam elevado grau de senescência, após o período considerado viável ao consumo. Isto foi verificado em todos os estádios, de ambas variedades.

A máxima produção de etileno, na variedade Kumagai, antecedeu o completo amadurecimento no estádio 1, coincidiu com o completo amadurecimento para o estádio 2 e foi posterior ao completo amadurecimento no estádio 3. Na variedade Paluma, a máxima produção de etileno ocorreu após o completo amadurecimento dos frutos, em todos os estádios.

O pico da atividade respiratória e da produção de etileno, não corresponderam ao período de intensas transformações físico-químicas, independente dos estádios de maturação. Possivelmente, esses processos do amadurecimento não necessitem do valor máximo de etileno, mas apenas da presença deste. Segundo Abeles et al. (1992), o etileno é um sinalizador do amadurecimento, sendo fisiologicamente ativo em concentrações de $0,1 \mu 1 .^{-1}$.

Azzolini (2002) observou o mesmo comportamento em goiabas 'Pedro Sato' de três estádios de maturação. Argenta (1993), observou redução da firmeza e aumento dos teores de SS antes do pico de produção de etileno para maçãs 'Golden Delicious' e 'Fuji'. Em pêssegos 'Shiro' e 'Rubyred', a síntese de etileno continua após o amadurecimento, porém o nível deste fitohormônio é baixo (Abdi et al., 1997).

Yang (1985), afirma que o que leva ao amadurecimento é a diminuição da resistência à ação do etileno, portanto, o aumento da produção de etileno não seria prérequisito para iniciar o amadurecimento. $\mathrm{O}$ autor classifica os frutos climatéricos em frutos do tipo I, os quais apresentam aumento na produção de etileno antes do começo do amadurecimento; e frutos do tipo II, nos quais o começo do amadurecimento não é precedido pelo aumento da produção de etileno.

Sendo assim, a classificação dos frutos em climatérico e não climatérico é uma simplificação do processo de amadurecimento. 


\section{CONCLUSÕES}

- Os índices de maturação mais adequados para goiabas 'Kumagai' são cor da casca e firmeza da polpa, enquanto que para as goiabas 'Paluma' são cor da casca, firmeza e "ratio".

- Goiabas 'Kumagai' e 'Paluma', colhidas nos estádios 4 e 5 , atingem menor acidez titulável e maior 'ratio'.

- A melhor qualidade sensorial para goiabas 'Kumagai'é obtida quando os frutos são colhidos nos estádios 4 e 5, e para goiabas 'Paluma' quando os frutos são colhidos no estádio 5 .

- Goiabas 'Kumagai' e 'Paluma', são variedades climatéricas, no entanto, apresentam pico de produção de $\mathrm{CO}_{2}$ e de etileno após o completo amadurecimento dos frutos. 


\section{REFERÊNCIAS BIBLIOGRÁFICAS}

ABDI, N.; HOLFORD, P.; McGLASSON, W.B.; MIZRAHI, Y. Ripening behaviour and responses to proprylene in four cultivares of Japanese type plums. Postharvest Biology and Technology, v. 12, p. 21-34, 1997.

ABDI, N.; McGLASSON, W.B.; HOLFORD, P.; WILLIAMS, M.; MIZRAHI, Y. Responses of climateric and supressed-climacteric plums to treatment with propylene and 1- methylcyclopropene. Postharvest Biology and Technology, v.14, p.29-39, 1998.

ABELES, F.B.; MORGAN, P.W.; SALTVEIT, M.E. Ethylene in Plant Biology. San Diego: Academic Press, 1992. 414p.

ADSULE, R.N.; KADAM,S.S. Guava. In: SALUNKHE, D.K.; KADAM, S.S. (Ed.). Handbook of fruit science and technology, production composition, storage and processing. New York: Marcel Dekker, 1995. cap. 9, p.419-433.

AKAMINE, E.K.; GOO, T. Repiration and ethylene production in fruits of species and cultivars of Psidium and species of Eugenia. Journal of the American Society for Horticultural Science, v.104, n.5, p.632-635, 1979.

ASSOCIATION OF OFFICIAL ANALYTICAL CHEMISTS. Official methods of analysis of AOAC international. Food composition, additives, natural contaminants. S.L.: AOAC international, 1995. cap.37, p.1-23. 
ARGENTA, L.C. Concentração de etileno interno e maturação de maçãs cvs. Gala, Golden Delicious e Fuji. Revista Brasileira de Fruticultura, v.15, n.1, p.125-132, 1993.

AWAD, M. Fisiologia pós-colheita de frutos. São Paulo: Nobel, 1993. 114p.

AZZOLINI, M. Fisiologia pós-colheita de goiabas 'Pedro Sato' : estádios de maturação e padrão respiratório. Piracicaba, 2002. 100 p. Dissertação (Mestrado) - Escola Superior de Agricultura “Luiz de Queiroz”, Universidade de São Paulo.

BIALE, J.B. The postharvest biochemestry of tropical and subtropical fruits. Advances in Food Research, v.10, p.293-354, 1960.

BIALE, J. B.; BARCUS, D. E. Respiratory patterns in tropical fruits of the amazon Basin. Tropical Science, v.12, p.93-104, 1970.

BLEINROTH, E W Tecnologia do pos colheita de frutas tropicais Campinas : Ital, 1992. 203 p.

BLEINROTH, E. W. Colheita e beneficiamento. In: GONCATTI NETO, A.; GARCIA, A.E.; ARDITO, E.F.G.; GARCIA, E.E.C.; BLEINROTH, E.W.; MATALIO, M.; CHITARRA, M.I.F.; BORIN, M. R. Goiaba para exportação: procedimentos de colheita e pós-colheita. Brasília: EMBRAPA, 1996 cap.2, p.12-23. (Série Publicações Técnicas FRUPEX, 20).

BOTELHO, R.V. Efeito do tratamento pós-colheita com cálcio na ocorrência de antracnose (Colletotrichum gloeosporioides Penz) e no amadurecimento de goiabas (Psidium guajava L.) Botucatu, 1996. 122p. Dissertação (Mestrado)- Faculdade de Ciências Agronômicas, Universidade Estadual Paulista "Julio de Mesquita filho". 
BRODY, A.L. Envasado de alimentos en atmosferas controladas, modificadas y vacio. Zaragoza: Acribia, 1996. 220p.

BROWN, B.I.; WILLS, R.B.H. Post-harvest changes in guava fruit of different maturing. Scientia Horticulturae, v.19, n.3/4, p.237-243, 1983.

EL-BULUK, R.E.; BABIKER, E.F.E.; EL-TINAY, A.H. Biochemical and physical changes in fruits of four guava cultivars during growth and development. Food Chemistry, v.34, p.279-282, 1995.

EL-BULK, R.E.; BABIKER, E.F.E.; EL-TINAY, A.H. Changes in chemical composition of guava fruits during development and ripening. Food Chemistry, v.59, n.3, p.395-399, 1997.

CARVALHO, V.D. Qualidade e conservação pós-colheita de goiabas. Informe Agropecuário, v.17, n.179, p.48-54, 1994.

CASTRO, J.V. SIGRIST, J.M.M: Matéria-prima. In: MEDINA, J.C.; CASTRO, J.V.; SIGRIST, J.M.M; MARTIN, Z.; KATO, K.; MAIA, M.L.; GARCIA, A.E.B.; LEITE, R.S.S.F. Goiaba: cultura, matéria- prima, processamento e aspectos econômicos. 2.ed. Campinas: ITAL, 1988. cap.2, p. 121-140. (Série Frutas tropicais, $6)$.

CHAN JÚNIOR, H.T.; KWOK, S.C.M. Identification and determination of sugars in some tropical fruit products. Journal of food Science, v.40, n.2 p. 419-420, 1976.

CHITARRA, M.I.F. Características das frutas de exportação. In; GONGATTI NETO, A.; GARCIA, A. E.; ARDITO, E. F.G.; GARCIA, E.E.C.; BLEINROTH, E.W.; MATALLO, M.; CHITARRA, M.M.I.F.; BORDIN, M. R. Goiaba para exportação: 
procedimentos de colheita e pós-colheita. Brasília; EMBRAPA, 1996. cap.1, p.9-11. (Série Publicações Técnicas FRUPEX, 20).

CHITARRA, M.I.F.; CHITARRA, A.B. Pós-colheita de frutos e hortaliças: fisiologia e manuseio. Lavras: ESAL; FAEPE, 1990. 320p.

CHITARRA, M.I.F.: CHITARRA, A.B. CARVALHO, V.D. Algumas características dos frutos de duas cultivares de goiabeira (Pisidium guajava L ) em fase de maturação. In: CONGRESSO BRASILEIRO DE FRUTICULTURA, 6. Recife, 1981, Anais. Recife: SBF, 1981. v.2, p.771-780.

CLYDESDAL, F.M. Color as a factor in food choice. Critical Reviews in Food Science and Nutrition, v.33, n.1, p.83-101, 1993.

CROSS, J. Pigments in fruits. London: Academic Press, 1987. 303p.

DHILLON, B.S.; SINGH, S.N.; KUNDAL, G.S.; MINHAS, P.P.S. Studies on the developmental physiology of guava fruti (Psidium guajava L.) II. Biochemical characters. Punjab Horticultural Journal, v.27, n.3/4, p.212-221, 1987.

DHINGRA, M.K.; GUPTA, O.P.; CHUNDAWAT, B.S. Studies on pectin yield ad quality of some guava cultivares in relation to cropping season and fruit maturity. Journal of Food Science and technology, v.20, n. 1/2, p.10-13, 1983.

EL-BULK, R.E.; BABIKER, EL F.E.; EL TINAY, A.H. Changes in chemical composition of fruits during development and ripening. Food chemistry, v. 59, n.3, p.395-399, 1997. 
EL- ZOGHIBI, M. Biochemical changes in some tropical fruits during ripening. Food Chemistry, v. 59, n.3, p. 395-399, 1994.

ESTEVES, M.T. da C.; CARVALHO, V. D. de. Modificações nos teores de amido, açúcares e grau de doçura de frutos de seis cultivares de goiabeira (Psidium guajava L.) em diferentes estádios de maturação. Ciência e Prática, v. 6, n.2, p.208-218, 1982.

ESTEVES, M.T. da C.; CARVALHO, V.D. de.; CHITARRA, M.I.F.; CHITARRA, A.B.; PAULA, M.B de. Caracterização dos frutos de seis cultivares de goiabeiras (Pisidium guajava L.) na maturação. I -Determinações físicas e químicas. In: CONGRESSO BRASILEIRO DE FRUTICULTURA, 7., Florianópolis, SC. 1983, Anais Florianópolis SC: SBF, 1984, v.2, p.477-489.

FLUHR, R., MATTOO, A.K. Ethylene-biosynthesis and perception. Critical reviews in Plant Sciences, v.15, n.5/ 6, p. 479-523, 1996.

FNP CONSULTORIA \& COMÉRCIO. Agrianual 2004: anuário estatístico da agricultura brasileira. São Paulo, p. 314-318, 2004.

GERHARDT, L.B.A.; MANICA,I.; KIST, H.; SIELER, R.L. Características físicoquímicas dos frutos de quatro cultivares e três clones de goiabeira em Porto Lucena, RS. Pesquisa Agropecuária Brasileira, v.32, n.2, p.185-192, 1997.

GERASOPOULOS, D.; RICHARDSON, D.G. Effects of exogenous propylene and fruit calcium on ripening of non-chilled and chilled Anjou pears. Postharvest Biology and Technology, v.8, p.111-120, 1996. 
GIANONNI, J. A. Efeito da radiação gama e do cálcio na conservação pós-colheita da goiaba branca armazenada sob refrigeração. Botucatu, 2000. 181p. Dissertação (Mestrado)- Universidade Estadual Paulista "Júlio de Mesquita Filho".

GIOVANNONI, J. Molecular biology of fruit maturation and ripening. Annual Review Plant Physiology Plant Molecular Biology, v.52, p.725-749, 2001.

GRIERSON, D. Senescence in Fruits. HortiScience, v.22, n. 5, p.859-862, 1987.

JACOMINO, A.P. Conservação de goiabas 'Kumagai' em diferentes temperaturas e materiais de embalagem. Piracicaba, 1999. 90p. Tese (Doutorado)- Escola Superior de Agronomia “Luiz de Queiroz”, Universidade de São Paulo.

JACOMINO, A P; MARTINEZ OJEDA, R; KLUGE, R A. Conservação de goiabas tratadas com emulsões de cera de carnaúba. Revista Brasisleira de Fruticultura, v.25, n.3, p.401-405, dez. 2003.

JAIN,N.; DHAWAN,K.; MALHOTRA,S.P.; SIDDIQUI,S.; SINGH,R. Compositional and enzymatic changes in guava (Psidium guajava L.) fruits during ripening. Acta Physiologiae Plantarum, v.23, n.3, p.357-362, 2001.

KADER, A.A. Biochemical and physiological basis for effects of controlled and modified atmospheres on fruits and vegetables. Food Technology, v. 40, n.5, p.102-104, 1986.

KADER, A.A. Postharvest technology of horticultural crops technical. 2.ed. Oakland, Ca.: University of California, Division of Agriculture and Natural Resources, 1992. $296 \mathrm{p}$ 
KLUGE, R. A.; NACHTIGAL, J.C.; BILHALVA, A.B. Fisiologia e manejo póscolheita de frutas de clima temperado. 2. ed. Pelotas: UFPEL, 2002. 163p.

KNEE, M.: Evaluanting the pratical significance of ethylene in fruit storage. In: ROBERTS, J.A.; TUCKER, G.A. Ethylene and plant development. London: Butterworths, 1985. p.297-315.

LELIEVRE J.M.; LATCHE, A.; JONES, B.; BOUZAYEN, M. PECH J.C. Ethylene and fruit ripening. Physiology Plantarum, v. 101, p.727-739, 1997.

LIMA, M.A.; DURIGAN, J.F.; TOSTES, D.R.D. Avaliação do comportamento respiratório de goiabas 'Pedro Sato' e a influência de diferentes embalagens na sua conservação sob refrigeração. In: CONGRESSO BRASILEIRO DE CIÊNCIA E TECNOLOGIA DE Alimentos, 16., Rio de Janeiro, 1998. Anais. Rio de Janeiro: SBCTA, p. 1980-1983, v.3. 1998.

LIMA, M.A.; DURIGAN, J, F. Conservação de goiabas 'Pedro Sato' associando-se refrigeração com diferentes embalagens. Revista Brasileira de fruticultura, v.22, n.2, p. 232-236, 2000.

MANICA, I.; ICUMA, I.M.; JUNQUEIRA, N.T.V.; SALVADOR, J.O.; MOREIRA, A.; MALAVOLTA, E. Fruticultura tropical. Porto Alegre: Cinco continentes, 2000. cap.6. 373p: Goiaba

MATTOO, A. K.; SUTTLE, J.C. The plant hormone ethylene. Florida: CRC Press, 1991. 337p.

McGLASSON, W.B. Ethylene and fruit ripening. HortScience, v.20, n.1, p. 51-54, 1985. 
McGUIRE, R.G. Reporting of objective color measurements. HortSciencen, vol.27, n.12, dec., 1992. p.1254-1255.

McMURCHIE, E.J.; McGLASSON, W.B.; EAKS, I.L. Treatment of fruit with propylene gives information about the biogenesis of ethylene. Nature, v. 273, p.235-236, 1972.

MEDINA, J.C. Goiaba, da cultura ao processamento e comercialização. Campinas, Governo do Estado de São Paulo, Secretaria da Agricultura, Coordenadoria da Pesquisa Agropecuária, Instituto de Tecnologia de Alimentos, 1978. 106 p. (Série Frutas tropicais, 6).

MEDINA, J.C.;CASTRO, J.V.; SIGRIST, J.M.M.;MARTIN, Z.J.; KATO, K.; MAIA, M.L.; GARCIA, A.E.B.; LEITE, R.S.S.F. Goiaba. 2.ed. Campinas: Ital, 1991. p.17.(Frutas Tropicais, 6).

MERCADO-SILVA,E.; BAUTISTA,P.B.; GARCIA-VELASCO,M.A. Fruit development, harvest index ripening changes of guavas produced in central Mexico. Postharvest Biology and Technology, v.13, n.2, p.143-150, 1998.

MOKADY, S.; COGAN, U.; LIEBERMAN, L. Stability os vitamin C in fruit and fruit blends. Journal Science Food Agricultural, v.35, p.452-456, 1984.

MOWLAH, G.; ITOO, S. Guava (Psidium guajava L.) sugar components and related enzymes at stages of fruit- development a ripening. Journal of Japanese Society of Food Science and Technology, v.29, n.8, p.472-476, 1982.

NULTSCH, W. Botânica geral. Trad. de P.L. de Oliveira. Porto Alegre: Artes Médicas Sul, 2000. 489p. 
OETIKER,J.H.; YANG,S. F. The role of ethylene in fruit ripening. Acta Horticultural, v.398, p.167-178, 1995.

OJEDA, R, M. Utilização de ceras, fungicidas e sanitizantes na conservação de goiabas 'Pedro Sato' sob condição ambiente. Piracicaba, 2001. 57p. Dissertação (Mestrado)- Escola Superior de Agricultura “Luiz de Queiroz”, Universidade de São Paulo.

OLIVEIRA, M.A. Utilização de película de mandioca como alternativa à cera comercial na conservação pós-colheita de frutos de goiaba (Psidium guajava). Piracicaba, 1996. 73p. Dissertação (Mestrado)- Escola Superior de Agricultura "Luiz de Queiroz”, Universidade de São Paulo.

OLLER, P.W.; MIN-WONG, L.; TAYLOR, L.P.; PIKE, D.A.; THEOLOGIS, A. reversible inhibition of tomato fruit senescence by antisense RNA. Science, v.254, p.437-439, 1991.

PELLETIER, O.; BRASSARD, R. Determination of vitamin C (L- ascorbic acid and dehydroascorbic acid) in food by manual and automated photometric methods. Journal of Food Science, v. 42, n.6, p. 1471-1477, 1977.

PEREIRA, F.M. Cultura da goiabeira. Jaboticabal: Funep, 1995. 47p.

PERYAM, D.R.; GIRARDDOT, N. F. Advanced taste method. Food Engeneiring, v.24, p.58-61, 1952.

PIVETTA, K.F.L., DURIGAN, J.F.; PEREIRA, F.M. Avaliação da conservação póscolheita, em condições ambientais, de frutos de goiabeira (Psidium guajava L.) 
colhidos em diferentes estádios de maturação. Revista Brasileira de Fruticultura, v.14, n.3, p.236-239, 1992.

PURVIS, A. C. The role of adaptive enzymes in carbohydrate oxidation by stressed and senescing plant tissues. Hortscience, v.32, n.7, p.195-168, 1997.

RATHORE, D.S. Effect of season on growth and chemical composition of guava (psidium-guajavaL) fruits. Journal of Horticultural Science, v. 51 n.1, p. 41-47, 1976.

REYES REYES, F.G.; MARIN, M.S.; BOLANÕS, M.A de. Determinação de pectina na goiaba (Psidium guajava L.). Revista Brasileira de Tecnologia, v.7, n.3, p.313315, 1976.

RHODES, M.J.C. The maturation and ripening of fruits. In:THIMANN, K.V.; ADELMAN, R. C.; ROTH, G. S. Senescence in plants. Florida: CRC Press,. cap.8, p.157-205, 1980.

ROMANI, R. J. Respiration, ethylene, senescence, and homeostasis in an integrated view of postharvest life. Canadian Journal of Botany. v.62, n.12, p.2950- 2955, 1984.

SEYMOUR, G.B.; TAYLOR, J.E.; TUCKER, G. A. Biochemestry of fruit ripening. London: Chapmal \& Hall, 1993. 454 p.

SINGH, B.P.; SINGH, H.K.; CHAUHAN, K.S. Effect of post-harvest calcium treatments on the storage life of guava fruits. Indian Journal Agricultural Science, v.51, n.1, p.44-47, jan, 1981. 
SMIRNOFF, N.; CONKLIN, P.; LOEWUS, F.A. Biosynthesis of ascorbic acid in plants: A renaissance. Annual Review of Plant and Physiology and Plant Molecular Biology, v.52 p. 437-467, 2001.

TAIZ, L.; ZEIGER, E. Plant physiology, 3.ed.. Porto Alegre: Artmed, 2004. cap. 22, p.541-559: Etileno.

TEAOTIA, S.S., TRIPATHI,R.S.; BHAN,S. Evaluation of indices for determination of maturity of guava (Psidium guajava) Horticulaturae, Advance, v.7, p. 99-107, 1970.

TUCKER, G.A. Introduction. In:SEYMOUR, G.B.; TAYLOR, J.E.; TUCKER, G. A. Biochemestry of fruit ripening. London: Chapmal \& Hall, 1993. cap.1, p. 2-51.

VAZQUEZ-OCHOA, R.I.; COLINAS-LEON, M.T. Changes in guavas of three maturity stages in response to temperature and relative humidity. Horticultural Science, v.25, n.1, p. 86-87, 1990.

VENDRELL, M.; PALOMER, X. Hormonal control of fruti ripening in climateric fruits. Acta Horticulturae, n.463,. p.325-334, 1997.

WATADA, A.E.; HERNER, R.C.; KADER, A.A.; ROMANI, R.J.; STABY, G.L. Terminology for the description of developmental stages of horticultural crops. HortScience, v. 19, n.1, p.20-21, 1984.

WILLS, R.; McGLASSON, B.; GRAHAM, D.; JOYCE, D. Introducción a la fisiología y manipulación poscosecha de frutas, hortalizas y plantas ornamentales. Trad. de J.B. Gonzáles. 2.ed. Zaragoza: Acribia, 1998. 240p. 
WILlS, R.H.H.; LEE, T.H.; GRAHAM, W.B.; HALL, E.G. Postharvest- an introduction to the physiology and handling of fruit and vegetables. Kensington: New South Wales University Press, 1981. 161p.

XISTO, A.L.R.P. Conservação pós-colheita de goiaba 'Pedro Sato'com aplicação de cloreto de cálcio em condições ambiente. Lavras, 2002. 47p. Dissertação (Mestrado)-Universidade Federal de Lavras.

YANG, S. F. Biosynthesis and action of ethylene. HortScience, v.20, n.1, Feb, 1985. p.41-45.

YEN, H.C.; LEE, S.; TRANKSLEY, S.D.; LANAHAN, M.B.; KLEE, H.J.; GIOVANNONI, J.J. The tomato never-ripe locus regulates ethylene inducible gene expression and is linked to a homolog of the Arabidopsis ETR1 gene. Plant Physiology, v. 107, p.1343-1353, 1995. 
APENDICE 
FICHA DE AVALIAÇÃO PARA ANÁLISE SENSORIAL DE GOIABAS

Nome:

data:

Por favor, prove e avalie de acordo com a escala abaixo.

\begin{tabular}{|c|c|c|c|c|c|c|c|}
\hline & \multicolumn{7}{|c|}{ Notas - Número da Amostra: } \\
\cline { 2 - 8 } Variáveis & $\begin{array}{c}\text { (1) } \\
\text { Péssima }\end{array}$ & $\begin{array}{c}\text { (2) } \\
\text { Muito } \\
\text { Ruim }\end{array}$ & $\begin{array}{c}\text { (3) } \\
\text { Ruim }\end{array}$ & $\begin{array}{c}\text { (4) } \\
\text { Regular }\end{array}$ & $\begin{array}{c}\text { (5) } \\
\text { Boa }\end{array}$ & $\begin{array}{c}\text { (6) } \\
\text { Muito } \\
\text { Boa }\end{array}$ & $\begin{array}{c}\text { (7) } \\
\text { Ótima }\end{array}$ \\
\hline Odor & & & & & & & \\
\hline Sabor & & & & & & & \\
\hline Textura & & & & & & & \\
\hline Aparência & & & & & & & \\
\hline $\begin{array}{c}\text { Qualidade } \\
\text { Global }\end{array}$ & & & & & & & \\
\hline
\end{tabular}

O que você mais gostou? (Por que?)

O que você menos gostou? (Por que?) 